\title{
The Value of Control in Emerging Markets
}

\author{
Anusha Chari \\ University of North Carolina at Chapel Hill \\ Paige P. Ouimet \\ University of North Carolina at Chapel Hill \\ Linda L. Tesar \\ University of Michigan and NBER
}

\begin{abstract}
This paper examines shareholder value gains from developed-market acquisitions of emerging-market targets. On average over the 1988-2003 period, abnormal returns for developed-market acquirers show an anomalous increase of $1.18 \%$ over a three-week event window when M\&A transactions in emerging markets are announced. For a sample of 390 transactions, market-adjusted returns translate to an aggregate dollar value gain of $\$ 111.5$ billion for shareholders of acquiring firms. Acquirer returns triple to 4.43\% when majority control of the target is acquired. Surprisingly, the median net return (acquirer's dollar value gain/transaction value) is 1.37 with the acquisition of control. We offer a possible explanation for these puzzling findings - the data suggest that improved governance (via control rights) and the transfer of intangibles such as $R \& D$ or brand value from acquirers to targets explain the revaluation in acquirer stock prices and the resulting dollar value gains in emerging market transactions.
\end{abstract}

JEL Codes: G15, G34.

Keywords: intangible assets, institutions, FDI flows, emerging markets, mergers and acquisitions, acquirer returns.

Contact Information: Anusha Chari, Visiting Assistant Professor of Economics, Department of Economics and International Policy Center, Gerald R. Ford School of Public Policy, University of Michigan, 611 Tappan Street, Ann Arbor MI 48109. Internet: achari@umich.edu. Paige Ouimet, pshelby@umich.edu. Linda Tesar, ltesar@umich.edu. We thank our discussants Lee Branstetter, Arturo Bris, Michael Dooley, Atif Mian, Leora Klapper and Karl Lins. We also thank Andrew Bernard, Joshua Coval, Amy Dittmar, Mara Faccio, Fritz Foley, Terry Odean, Avanidhar Subrahmanyam, Luigi Zingales and seminar participants at Berkeley, Dartmouth, the IMF, Michigan, Princeton, Stanford, UC Santa Cruz, USC, Vanderbilt, Virginia, the Federal Reserve, IFM-NBER Summer Institute, NBER Productivity Meeting, EFA Meeting-Maastricht, WFA 2005, Indian School of Business and the $9^{\text {th }}$ Mitsui Life Emerging Markets Symposium for helpful comments and suggestions. Chari and Tesar acknowledge a grant from the Center for International Business Education at the University of Michigan. 


\section{Introduction}

Foreign acquisitions extend the boundaries of the firm across national borders. In the context of emerging markets, these boundaries are extended across countries with vast asymmetries in institutions and property rights protections. Foreign acquisitions in emerging markets therefore present a natural laboratory to study value creation in settings where problems of incomplete contracting and non-verifiable monitoring are likely to be especially severe. In the late 1980s and early 1990s, many emerging markets enacted reforms to liberalize international capital flows including foreign direct investment allowing foreign corporate control (Henry, 2006; Kose, Prasad, Wei and Rogoff, 2006). Following these reforms, there was a rapid expansion of FDI flows to emerging markets with an increasing fraction taking the form of foreign acquisitions of existing plant and equipment rather than green-field FDI. In this paper we examine the returns to shareholders of developed-market firms that undertook acquisitions in emerging markets.

We begin by uncovering three stylized facts. First, between 1988 and 2003, developedmarket firms experienced abnormal returns of $1.18 \%$ standardized monthly return over a threeweek event window when an emerging-market acquisition was announced. ${ }^{1}$ In the context of the well-documented average underperformance of acquiring firms in US M\&A transactions (Andrade, Mitchell, and Stafford, 2001; Moeller, Schlingeman and Stulz, 2005), this return is somewhat anomalous. It is also fairly substantial when viewed in relation to the size of acquiring firms in these transactions. Market-adjusted returns translate to an aggregate dollar value gain of \$111.5 billion for shareholders of acquiring firms for a sample of 390 transactions that have both stock price and market capitalization values.

Second, positive acquirer returns are intimately linked to the acquisition of control in emerging markets-acquirer returns triple to $4.43 \%$ when majority control of the target is

\footnotetext{
${ }^{1}$ The result is robust to the inclusion of controls for country, time, industrial diversification, method of payment effects, as well as acquirer- and target-firm characteristics such as size and liquidity.
} 
acquired. The aggregate dollar value gain is $\$ 75.6$ billion in transactions that involve majority control. Acquisitions of minority stakes, in contrast, do not deliver significant acquirer returns. Third, the median transaction value in an emerging-market acquisition where control is acquired is $\$ 110.5$ million. The median acquirer stock price reaction suggests a median dollar value gain of $\$ 104.6$ million. The data suggest that on a transaction by transaction basis the median net return (acquirer's dollar value gain/transaction value) is 1.37 when control is acquired.

We conduct a number of tests to ensure the robustness of our results. First, we verify that the positive acquirer returns are robust to the length of the event window and are not driven by survivorship bias at the level of the target country. In addition to including a series of controls for firm characteristics, we also establish that $50 \%$ is the critical threshold that drives the positive acquirer returns. To address concerns about selection bias, we extend our analysis to include publicly-listed targets in developed markets that were acquired by the acquirers in our sample. Consistent with the evidence in the previous literature, we find that acquirer returns in developed market M\&As are not significant. Acquirer returns are significant only in emerging-markets transactions that involve a transfer of majority control.

These puzzling findings prompt the following questions. First, why is the acquisition of control a necessary condition for positive acquirer returns in emerging markets? Second, how can we account for the anomalous magnitude of the shareholder value gains to foreign acquirers in emerging markets?

We hypothesize that acquiring majority control allows firms to overcome problems of incomplete contracting that plague emerging markets. A central prediction of the 'property rights' theory of the firm is that when there are significant complementarities between assets, placing them under the control of a single firm can resolve problems associated with incomplete contracting (Grossman and Hart, 1986; Hart and Moore, 1990; Hart, 1995). For example, acquirers may be more likely to share proprietary technologies and intangible assets such as brand 
name when they acquire majority control of the target, especially in settings with non-verifiable monitoring (Holmstrom and Tirole, 1997) and weak investor protections.

We develop a simple analytical framework to offer a possible explanation for the potential sources of acquirer gains when a developed-market firm obtains majority control of an emerging-market target in the context of incomplete contracting and segmented financial markets. We show that the developed-market acquirer return will be an increasing function of: (i) the value of intangible assets that can be transferred from the acquirer to the target, $^{2}$ (ii) the asymmetry between developed and emerging market institutions, ${ }^{3}$ (iii) the complementarity between asset intangibility and institutional protection, (iv) weakness in the bargaining power of the target, and (v) the cost of capital in the emerging market. We examine the role of each of these factors in turn as an explanation for the large acquirer returns in emerging markets.

First, we test whether the ability of acquirers to bring intangible assets to target firms drives the increase in acquirer market values (dollar value gains). The data suggest that the abnormal announcement returns and dollar value gains are the largest when associated with a transfer of control in settings with the largest intangibles, i.e., in industries with high R\&D and brand intensity. ${ }^{4}$

Second, the evidence suggests that ability of developed-market acquirers to bring better institutions via control rights to emerging-market targets is a source of value gains for shareholders of acquiring firms. Acquirer returns and dollar value gains are significantly higher when acquirers gain majority control of targets in countries with high risks of expropriation, contract repudiation, and weak rules of law.

\footnotetext{
${ }^{2}$ Morck and Yeung $(1991,1992)$ provide empirical evidence on the internalization theory of synergy in the context of geographic diversification. Morck and Yeung (2002) argue that a mechanism to overcome settings with transaction difficulties is to internalize the markets for information-based assets by bringing the buyers and sellers together within the same firm.

${ }^{3}$ Stulz (2005) provides an argument that financial globalization enables emerging market firms to rent investor protection mechanisms from foreigners countries. Also, see Holmstrom and Kaplan (2001) for an anlalysis of corporate governance and merger activity.

${ }^{4}$ Morck and Yeung (2002) argue that a solution for a firm to obtain value from expanding the application of its intangibles to other firms' operations is to "internalize" the market for these intangibles by acquiring the productive assets of the other firms.
} 
Third, we find that in a pooled sample of developed and emerging market targets, the complementarity between asset intangibility and control deliver positive acquirer returns only in emerging markets. The finding supports the view that an additional benefit of importing better institutions from developed markets is the transfer of intangible assets from the acquirer to the target.

Fourth, the ability of acquirers to capture the surplus value gains embodied in emerging market transactions is likely to be driven by the strong bargaining position of developed-market firms relative to emerging market targets. We find that only a small fraction of our transactions involve competing bids and that the developed-market acquirer firms are an order of magnitude larger than target firms in emerging markets. The absence of competing bidders and the difference in relative size between acquirers and targets in conjunction with multinational access to superior technology and international capital markets may all be factors that swing the relative bargaining power in favor of developed-market acquirers in emerging market M\&A.

Finally, in a world with imperfectly integrated capital markets, the ability of developedmarket firms to provide firms in capital-scarce emerging-markets with access to cheaper capital also may be a source of bargaining power for foreign acquirers. The results show that the stock price revaluation experienced by the acquiring firms is related to the cost of capital in emerging markets—acquirer returns increase as emerging-market spreads widen.

An alternative explanation for our finding of positive acquirer returns is that foreign acquirers are simply identifying undervalued assets in emerging markets rather than generating surplus value. However, if emerging-market assets are just "undervalued,” investors with no interest in corporate control, such as mutual funds and corporations interested in minority stakes, also should generate positive returns (Coval and Stafford, 2007). Our results suggest that the acquisition of majority control is a key feature of transactions that deliver positive acquirer returns. 
Our paper is related to the literature on cross-border activities of multinational firms in the context of costly financial contracting and weak investor protection. The findings in this paper complement those in Antras, Desai, and Foley (2007) who demonstrate that when multinational firms want to exploit technologies abroad, when monitoring is non-verifiable, and financial frictions exist, they deploy technology through ownership (FDI) as opposed to arm's length licensing. Note that, in contrast to portfolio equity investments, the mechanism by which FDI generates returns for foreign investors is by conferring control rights on them (Buiter, 2006). We find that, conditional on the acquisition taking place, returns to acquirers are a function of control in the face of weak institutions and incomplete monitoring, and the effect is more pronounced in industries with high asset intangibility. The finding is consistent with Morck and Yeung (1991) who argue that internalizing multinational firm operations may be more important in R\&Dintensive industries where the transfer of proprietary assets is an issue.

When acquirers from developed-markets takeover targets in emerging-markets they also may be purchasing relatively illiquid assets that cannot be bought or sold easily. Positive acquirer returns may therefore reflect an illiquidity discount in the valuation of emerging-market assets. The acquirer return results in this paper appear consistent with the pattern of returns in private firm acquisitions in the U.S. (Fuller, Netter and Stegemoller, 2002). ${ }^{5}$

Related international M\&A studies principally focus on the gains to target firms when they are acquired by firms operating in an environment with better investor protection. Notably, Rossi and Volpin (2004) show that firms in countries with poor investor protection are more likely to be targets in cross-border acquisitions. Starks and Wei (2004) suggest that takeover premiums for U.S. targets are decreasing in the foreign acquirer's home country governance for deals financed with the acquirer’s stock as the method of payment. Bris and Cabolis (2006) find that target abnormal returns increase with better shareholder protection and accounting standards

\footnotetext{
${ }^{5}$ Indirectly, the evidence is also consistent with the FDI literature that shows the multinational firm entry in developing countries drives local firms out of the market because multinational firms have better technology and access to international capital (Aitken and Harrison, 1999; Caves, 1996).
} 
in the acquirer's country of origin when the target is wholly acquired for a pooled sample of developed and emerging market transactions. Our paper shows that firms from countries with better investor protection experience significant gains when majority control of a target located in a country with weak investor protection is acquired.

Our findings also contribute to the current debate about the proper valuation of holdings of foreign assets (see, for example, Hausmann and Sturzenegger, 2006). Lipsey (2007) argues that, increasingly, the poor match between the stock and flow measures of foreign direct investment is attributable to the fact that more and more of production is the output from intangible and financial assets. A substantial missing component of value from transaction value estimates of foreign assets acquired is the value of intangibles such as technology, know-how, and brand name that firms from developed countries bring to emerging market firms (Hausmann and Sturzenegger, 2006). Viewed against the backdrop of the "dark matter” debate, shareholder value gains from cross-border M\&As can be interpreted as a market-based measure of the returns from investments in foreign assets.

The paper is organized as follows. Section 2 presents a simple theoretical framework illustrating the gains that accrue to acquiring firms through the transfer of technology, the extension of property rights protection through corporate control, and the lower cost of capital in industrialized countries relative to emerging markets. Section 3 describes the data. Section 4 establishes the positive acquirer gains and the link to control, and section 5 explores alternative sources of acquirer gains. Section 6 provides additional tests and robustness checks. Section 7 concludes.

\section{Acquirer Returns in Emerging Markets: A Simple Framework}

In the empirical analysis below we will use the stock market reaction to the announcement of an acquisition as our measure of the gains to acquirer and target shareholders. To fix ideas about the factors that might affect share prices around the time of an acquisition 
announcement, we develop a simple example in which a firm in an industrialized country acquires a firm in an emerging market. We assume that the announcement occurs at date $\tau$ and that the transfer of ownership is successfully completed immediately following the announcement.

Following standard asset-pricing theory, the market valuation of any firm i's project is given by:

$$
P_{s}^{i}=E_{t} \sum_{s=\tau}^{\infty} m_{s} \delta_{s}^{i}
$$

The stock price is the present discounted value of the firm's stream of dividends, $\delta_{s}$, paid to shareholders from $\tau$ to infinity, discounted by $m_{s}$, the cost of capital.

To capture differences in property rights protection between industrialized and emerging markets, we define $\gamma$ as an index of institutions, where $0<\gamma<1$, and the higher $\gamma$ is the weaker the set of institutions. One can think of $\gamma$ as a tax on the project operating under incomplete property rights protection. Let the index take on two values, $\gamma^{\mathrm{E}}$ for the index in emerging markets, $\gamma^{\mathrm{A}}$ for the index in the acquirer's market, where $\gamma^{\mathrm{E}}>\gamma^{\mathrm{A}}$. We define $\psi(\gamma)$ as an indicator of technology owned by the acquiring firm. The technology is an intangible asset, and we assume the payoff to the technology is decreasing in $\psi$, i.e., the better the property rights protection, the lower is $\gamma$ and the higher the payoff to the firm from the technology. ${ }^{6}$

The value of the target firm's project to local investors, operating under the institutions in the target's country, is given by:

(2) $\quad P_{\tau}^{T}=\sum_{s=\tau}^{\infty} m_{s}^{T} \delta_{s}\left(1-\gamma^{E}\right)$.

\footnotetext{
${ }^{6}$ Antras, Desai, and Foley (2007) develop a model of multinational investment with weak property rights, financial frictions, and nonverifiable monitoring. They show that weak institutions limit the extent of overseas investment and the degree to which the firm is willing to deploy technology abroad.
} 
The dividends of the project are discounted at the target market's rate $m_{s}^{T}$. We are implicitly assuming that the financial markets of the target and acquiring firms are segmented. Note that value of the project to local shareholders will be lower the weaker are local institutions (i.e. the higher is $\gamma^{\mathrm{E}}$ ). We do not model the source of the inefficiency stemming from weak institutions, but take this as a reduced from for problems in monitoring the firm's managers, corruption or other inefficiencies that reduce the payoff to shareholders.

The firm in the developed market could lease its technology to the emerging market firm. The value of the emerging market firm using the new technology but operating that technology under local control, and therefore under local institutions is:

$$
P_{\tau}^{L}=\sum_{s=\tau}^{\infty} m_{s}^{T} \delta_{s}\left(1+\psi\left(\gamma^{E}\right)\right)\left(1-\gamma^{E}\right)
$$

Because the project remains in local hands, the project is discounted at the target market's rate $m_{s}^{T}$. Under the assumption that the developed market firm captures all the gains from trade, the amount paid to the developed market firm to lease the technology would be:

$$
L=\sum_{s=\tau}^{\infty} m_{s}^{T} \delta_{s} \psi\left(\gamma^{E}\right)\left(1-\gamma^{E}\right)
$$

Alternatively, the developed market firm could acquire control, implement the technology, and operate the project under its own management. The value of the project would be:

$$
P_{\tau}^{T^{\prime \prime}}=\sum_{s=\tau}^{\infty} m_{s}^{A} \delta_{s}\left(1+\psi\left(\gamma^{A}\right)\right)\left(1-\gamma^{A}\right)
$$

where we make the strong assumption that the institutional rules that govern the firm are now those of the acquirer's country of origin, and the project is discounted at the acquirer's rate of discount. $^{7}$ To capture the notion that the cost of capital is higher in emerging markets relative to

\footnotetext{
${ }^{7}$ The idea here is that the acquiring firm gains full control of target, and therefore the accounting and management practices and the legal institutions that govern the acquiring firm in its home operations also
} 
industrialized countries, we will assume that $m_{s}^{A}(1+C C)=m_{s}^{T}$, where CC is the cost of capital differential in the two markets. Note that we assume that when the acquirer operates the technology, it does so under the protection of the institutions of the acquirer's home market. One could weaken this assumption by assuming less than complete transference of property rights protection, and therefore a smaller return to the technology when operated by the acquiring firm in its foreign operations, but the basic logic would still apply.

To assess acquirer gains, we need to compare the value of the target under foreign control, relative to the price the acquirer paid for the target. ${ }^{8}$ Let $P_{t}^{B}$ be the amount the acquirer bids for the target, where $\theta$ is an indicator of the extent to which the target price may be bid above its valuation on the local stock market and depends on the bargaining power of the target. Note that $\theta$ may depend on the existence of competing bidders.

$$
P_{\tau}^{B}=\sum_{s=\tau}^{\infty} m_{s}^{T} \delta_{s}\left(1-\gamma^{E}\right)(1+\theta)
$$

The return to the acquirer is then:

$$
R^{A}=P^{T^{n}}-P^{B}=\sum_{s=\tau}^{\infty} m_{s}^{T} \delta_{s}\left[\left(1+\psi\left(\gamma^{A}\right)\right)\left(1-\gamma^{A}\right)(1+C C)-\left(1-\gamma^{E}\right)(1+\theta)\right]
$$

Note that the payoff to control exceeds the benefits of leasing the technology. The acquirer return will be larger:

1. the larger the value of technology transfer $(\psi>0)$.

2. the larger the gap between institutions between the two countries $\left(\gamma^{\mathrm{E}}>\gamma^{\mathrm{A}}\right)$.

3. the greater the complementarity between technology and institutional protection $\left(\psi^{\prime}(\gamma)<\right.$ 0 and $\gamma^{\mathrm{E}}>\gamma^{\mathrm{A}}$ ). This suggests that acquirer returns will be greater when the acquirer gains control, particularly when institutions are weak and the technology involves intangibles.

apply to its subsidiaries. This is an extreme assumption and we use it here to illustrate the sense in which the boundaries of the firm are extended into the emerging market.

${ }^{8}$ Our example assumes that the gains to the acquirer stem solely from the operation of the technology in the target location. More generally, one could consider synergies between the target and acquiring firm that would increase the market valuation of the acquiring firm further. 
4. the weaker the bargaining power of the target, $\theta$.

5. the larger the cost of capital differential (liquidity effect as reflected in discount factors).

In the formal estimations below we examine whether the data are consistent with predictions 1-5 using an event-study methodology. We begin by describing our data set and take a first look at acquirer and target returns in foreign acquisitions of emerging-market targets.

\section{The Data}

Mergers and acquisitions as a mode of entry into emerging markets is a relatively new phenomenon. Foreign participation in emerging markets was fairly restricted until the 1990s when many emerging market countries deregulated their capital markets to foreign entry. For example, Latin American countries began actively seeking foreign investment in their newly privatized industries in the early 1990s. In a number of East Asian countries, however, prohibitions on foreign investors gaining a controlling share of local firms continued until the mid-1990s. The IMF bail-out packages to Thailand, Korea, and Indonesia following the East Asian crisis imposed additional conditions to allow foreign competition in the market for corporate control. Developed market M\&A transactions in East Asia and Latin America surged following the implementation of these policies. From 1991 through 2003 developed-market M\&A transactions accounted for $61 \%$ of foreign direct investment in Latin America and $48 \%$ in East Asia, up from $10 \%$ and $4 \%$ in the 1980 s. The cross-border merger wave in emerging markets therefore offers an international parallel to the deregulation-led domestic merger wave of the 1990s in the U.S. ${ }^{9}$

The data come from SDC Thompson’s International Mergers and Acquisitions database which covers public and private M\&A transactions involving at least 5\% ownership of the target company before 1992. After 1992, transactions of any size are included in the SDC database.

\footnotetext{
${ }^{9}$ Andrade, Mitchell, and Stafford (2001) argue that in explaining the causes of mergers and acquisitions in the domestic context, the 1990s were the "decade of deregulation."
} 
SDC collates information from more than 200 English and foreign language news sources, SEC filings and the filings from its international counterparts, trade publications, newswire reports, and proprietary surveys of investment banks, law firms, and other advisory firms.

To be included in the main sample, the M\&A transaction had to fulfill the following criteria. The acquirer had to be from a developed market, and the target had to be from an emerging market in East Asia or Latin America since these countries undertook policy measures to open up their markets for corporate control to foreign firms during the 1990s. The acquirer and target firms had to be publicly listed, and reliable stock price data had to be available for both the acquirer and the target for the calculation of joint returns. The observations covered transactions that resulted in a change in majority control in the target firm as well as acquisitions of minority shares. Finally, the transaction had to be completed.

With these filters in place, the sample covers the following countries. The target countries are Argentina, Brazil, Bolivia, China, Chile, Colombia, Ecuador, India, Indonesia, Malaysia, Mexico, Pakistan, Peru, Philippines, South Korea, Thailand, and Venezuela. The sample of developed-market acquirers includes firms from Canada, France, Germany, Hong Kong, Italy, Japan, Netherlands, Singapore, Spain, the United Kingdom, and the United States. Note that the Asian countries in the sample were the worst affected by the crisis in 1997. Argentina, Brazil, and Mexico also experienced crises during the sample period.

For each transaction, the SDC database provides information about the date on which the transaction was announced and the date on which the transaction became effective. The database also provides some characteristics of the target and acquiring firms such as name, nation, industry sector, and primary SIC classification. Many of the transactions contain transaction-specific information such as the percent of shares acquired, the percent of shares owned before and after the transaction was completed, and the percent of shares sought by the acquiring firm.

Table 1 presents the total number of transactions reported by the acquirer and target countries involving publicly listed firms in our initial sample. As a benchmark for evaluating the 
returns to acquisitions in emerging markets we include a sample of acquisitions by firms from developed markets of targets in a developed market. The developed-market acquirers in the sample made 1,708 acquisitions in emerging markets and 1,449 acquisitions in developed markets over the period 1988-2003. ${ }^{10}$ The table also presents the distribution of transactions by industrial sector. As the table shows there is no clear-cut concentration of transactions in any one sector. ${ }^{11}$

Table 2 shows the change in the extent of corporate control resulting from the M\&A transactions included in this paper. The columns of the table show the extent of ownership of the target prior to the acquisition, while the rows indicate post-acquisition ownership shares. Control information was available for 1,051 transactions in emerging markets and 882 developed-market transactions in SDC. The data show that in 868 out of 1,051 transactions, the developed-market acquirer had no ownership stake in the emerging-market target prior to the announcement (Panel A). In 799 transactions or about $75 \%$ of the sample, the acquisition leads to a majority or near complete transfer of control to the developed-market acquirer. Note that in about $12 \%$ of the sample, the acquirer had majority ownership of the emerging-market target prior to the acquisition. For the developed market target sample, about $79 \%$ of transactions involve the acquisition of majority control (Panel B).

Stock prices are from Datastream, Bloomberg, the ISI Emerging Markets Database and CRSP for the target and acquirer firms. Buy and hold returns are constructed using both daily and weekly stock price data. All returns are denominated in the local currency and the U.S. dollar. The initial sample covers 1,708 M\&A transactions by publicly traded developed-market acquirers that involve a publicly traded emerging-market target. Of these transactions, stock price data was available for 440 emerging-market firms. The main sample of emerging-market targets was

\footnotetext{
${ }^{10}$ To provide a more general view of the data, we use all available data in Tables 1 \& 2 rather than restricting the sample to transactions for which stock price information was available.

11 The number of transactions reported in the latter half of the sample (1996-2003) goes up significantly. This could in part be driven by improvements in SDC coverage of international transactions in the latter half of the 1990s. The formal estimations are conducted across different time periods to ensure that the results are robust over time.
} 
extended to include an additional 1,218 observations of developed-market acquisitions of publicly listed targets by the same developed-market acquirer firms. They were added to the sample to test if our results are specific to the emerging-market context.

\subsection{Acquirer Returns, Target Returns and Joint Returns}

This section provides a first look at acquirer, target, and joint returns when developedmarket acquirers announce acquisitions in emerging markets. We use weekly stock price data to compute raw buy-and-hold returns over the relevant event window around acquisition announcements. The second measure computes cumulative abnormal returns (CARs) over the event window using a market model.

$$
R_{i t}=\alpha_{i}+\beta_{i} R_{m t}+\varepsilon_{i t}
$$

The coefficients $\alpha_{i}$ and $\beta_{i}$ are estimated for a given firm over a one-year interval starting eighteen months prior to the announced acquisition and ending six months before the announcement. The coefficients are then used to compute weekly expected returns around the acquisition announcement. The abnormal return is defined as the difference between the actual return and the expected return in the event window. Abnormal returns are cumulative, due to continuous compounding over the event window.

The market returns used in the estimation are the broadest market index available for a particular country. ${ }^{12}$ Acquirer and target returns are calculated in terms of the local currency. Joint returns are based on returns in U.S. dollars and a market-capitalization-weighted average of individual acquirer and target returns consistent with Bradley, Desai, and Kim (1988).

\footnotetext{
${ }^{12}$ The following market indices were used for the developed markets in the sample: US (S\&P500), Canada (S\&P/TSX Composite Index), Japan (NIKKEI 300), Netherlands (Amsterdam European Options Exchange Index), Spain (IBEX 35), Italy (Milano Italia Borsa Index 30), UK (FTSE 100), Germany (DAX 30), France (CAC 40), Hong Kong (Hang Seng Index), and Singapore (Singapore All Equities Index). For the emerging markets, country returns from Datastream were used as the returns on the market index.
} 
We report results for a three-week event window which includes the week before, the week of, and the week after the announcement. The event window returns are standardized to monthly returns. For acquirers, we also measure returns over a three-day event window consistent with the domestic M\&A literature, reported in Table 9 (Panel A).

Panel A presents a first look at developed-market acquirer returns. The first cell in Panel A1 of Table 3 shows that shareholders of developed-market firms reap significant gains when an emerging-market target is acquired. For the full sample of developed-market acquirers (including minority and majority acquisitions), the average announcement return in the three-week event window is $2.31 \%$ in terms of raw returns and $1.18 \%$ in terms of cumulative abnormal returns (Panel A1). In contrast, while the average raw returns are positive and significant when the developed-market acquirers in the sample acquire developed-market targets, the cumulative abnormal returns are negative and significant when considering the test of medians (Panel A2).

The second cell in Panel A1 shows that acquirer returns increase significantly when majority control of an emerging-market target is acquired. Raw returns increase to $6.01 \%$, and cumulative abnormal returns are $4.43 \%$, on average, when majority control of emerging-market targets is acquired. Note also that acquirer returns are negative and insignificant when control of an emerging-market target is not acquired. Cumulative abnormal returns remain negative and significant when considering median returns when majority control of developed-market targets is acquired in Panel A2. The effect of gaining majority control on developed-market acquirer returns appears specific to the emerging-market context.

Announcement returns for emerging-market target firms are also positive and statistically significant (Panel B). In local currency terms, average announcement returns for the target firms in the three-week event window range from $6.49 \%$ to $6.62 \%$, depending on whether raw returns or market-adjusted returns are used. Emerging-market target returns also increase when the acquirer gains majority control; the average announcement returns range from $8.45 \%$ to $9.03 \%$ for emerging-market target firms. 
Market-capitalization-weighted, US\$-denominated, joint returns for developed-market acquirers and emerging-market targets are reported in Panel C. Joint returns are also positive, but only the raw returns are significant. Mirroring the pattern observed for acquirer and target returns, joint returns more than quadruple when a developed-market acquirer gains majority control of an emerging-market target.

Panel D presents market capitalization values for developed-market acquirers and emerging-market targets. The mean and median values for the acquirer market capitalizations are $\$ 40.59$ billion and $\$ 16.98$ billion, respectively. In contrast, the mean and median emergingmarket target market capitalizations are \$835.22 million and \$165.44 million.

In theory it would be interesting to compare shareholder value gains for acquiring firms in domestic transactions in emerging markets. The exercise could provide additional confirmation for whether acquirer returns are exclusive to developed-market transactions or are a general feature of M\&A transactions in emerging markets. Unfortunately, a lack of dependable stock price data for emerging-market firms makes this exercise unreliable. In addition the noise inherent in emerging-market stock prices may make it difficult to draw reliable inferences from such an exercise.

\section{The Acquisition of Control and Developed-Market Acquirer Returns}

Table 3 establishes that developed-market acquirer returns are positive and significant in the emerging market transactions. We now examine alternative sources of these gains suggested by the theoretical example in Section 2. Table 4 presents the results. The dependent variable is abnormal returns for acquirer firms during a 3-week event window around the announcement date. The intercept term in Column (1) shows that the coefficient for the average announcement returns for the acquirers is 0.012 and is significant at the $5 \%$ level. This estimate suggests that 
acquirer monthly abnormal returns increase by $1.2 \%$ in the three-week cross-border acquisition announcement window. ${ }^{13}$

Column (2) shows acquirer returns across subperiods. The time dummy for the latter half of the sample, 1996-2002, is significantly positive. Note that the intercept term now captures the early part of the sample, 1988-1995, and is negative and significant. Presenting the estimations across time addresses the concern that SDC coverage of international transactions improves following 1995. The fact that the acquirer returns are negative in the early part of the sample also may be driven by the fact that the early part of the sample is dominated by the acquisition of minority stakes in the targets.

The benchmark regression specification in Columns (3)-(8) for examining the effects of acquiring majority control on announcement returns is:

$$
R_{i t}=\alpha_{i}+\beta_{1} \cdot \text { Control }_{i}+\gamma_{j} \sum_{j=1}^{n} \text { AcquisitionCharacteristics }_{j}+\varepsilon_{i t}
$$

The left-hand side variable, $R_{i t}$, is the cumulative abnormal return for the three-week window that begins one week before and ends one week after the announcement of the acquisition. CONTROL is a dummy variable that takes on a value of one if the acquirer owns a $50 \%$ or more share of the target following the acquisition and did not have control before. Regressions in Columns (4)-(8) include country fixed effects.

The coefficient for CONTROL is 0.046 and is significant at the $1 \%$ level in Column (3) (Table 4). When combined with the coefficient on the intercept term, the estimate suggests that acquirer returns rise by $4.5 \%$ if the acquirer gains majority control of the target. The increase in acquirer returns suggests that cross-border M\&A transactions in emerging markets create shareholder value for developed-market acquirers. ${ }^{14}$

\footnotetext{
${ }^{13}$ The results remain robust to estimations conducted using a three-day and a five-week window.

${ }^{14}$ After controlling for variables such as acquirer size, target size, acquirer cash, and target industry, the coefficient on CONTROL is significant in alternative regression specifications. According to the regression estimates, the increase in acquirer returns ranges from $3.3 \%$ to $4.6 \%$ in alternative specifications. These
} 
Moreover, when CONTROL is included in the regression specifications in Column (4) with a dummy for the latter half of the sample (1996-2002), the coefficient estimate on the time dummy is no longer significant. The coefficient estimate for CONTROL is positive and significant at the $1 \%$ level. The finding indicates that acquisitions for control are more common in the latter half of the sample which is consistent with changing regulations in many emerging markets permitting the acquisition of majority control by foreign firms. The result also suggests that foreign firms preferred to acquire majority, if not complete control (90-100\% stakes), of targets in emerging markets once the regulations changed allowing majority acquisitions by foreign firms.

The estimations were repeated using market-capitalization-weighted joint returns as the dependent variable. The coefficient estimate for CONTROL continues to be positive and significant, ranging from 5.8\%-7.8\% in alternative specifications. ${ }^{15}$ Consistent with the pattern observed using acquirer returns, the results suggest that the acquisition of majority control is also a key feature of transactions that deliver positive combined-firm returns.

\subsection{Is the Acquisition of Majority Control a Critical Threshold?}

One concern about our definition of "majority control" is that it requires the acquisition of $50 \%$ or more shares of the target company. It is possible that de facto control of a company can be closely related to ownership concentration. For example, in diffusely held companies, effective control of the target may be achieved with a relatively small stake in the target. More important, the share price impact of an acquisition may depend upon the relative stake of that target that is purchased. The acquisition of a $5 \%$ stake may have a lower share price impact than a $90 \%$ stake.

results are not reported in the interests of saving space. Table 9 reports results for the three-day event window and includes controls for acquirer and deal characteristics. The coefficient on CONTROL continues to be positive and significant in the emerging market sample.

${ }^{15}$ The results are not reported in the paper in the interest of saving space but readily available from the authors. 
To ensure that our measure of majority control is robust, we run the estimations with a variety of alternative ownership measures.

First, we examine the impact of the relative stake of the target that is purchased using a continuous measure of ownership. The coefficient is positive and significant. A $1 \%$ increase in post-acquisition target ownership leads to a $0.04 \%$ increase in the acquirer abnormal returns (Table 4, Column (5)). However, when the majority control dummy is included in the regression specification, the coefficient on the post-acquisition ownership variable loses significance. Moreover, the coefficient on the majority control variable suggests a $5.4 \%$ increase in acquirer abnormal returns (Table 4, Column (6)). These results are consistent with the hypothesis that the transfer of control is an important determinant in acquirer announcement returns and that the variable, control, is not simply a proxy for the size of the acquired stake in the target. In unreported results, we use a log transformation of post acquisition ownership and again get similar results to those reported in column (6).

Second, we repeat the estimations in Columns (5) and (6) discrete ownership bins. The results show that acquiring $90 \%$ or more of the target company drives acquirer abnormal returns up by 3.7\% while acquiring between 50\%-90\% drives up returns by 5.4\% (Table 4, Column (7)). When the majority control variable is included in the estimations, the coefficient on the $90 \%$ or greater ownership variable loses significance (Column (8)). In summary, the results in Table 4 suggest that the acquisition of majority control appears to be a critical threshold that drives positive developed-market acquirer returns.

\subsection{Dollar Value Gains for Shareholders of Developed-Market Acquirers and Emerging- Market Targets}

To get a sense of the magnitude of the shareholder wealth creation from a typical acquisition, Table 5 shows the distribution of cumulative abnormal returns and dollar value gains for developed-market acquirers. Panel A shows a median CAR of $4 \%$ in transactions where control is acquired. In contrast, the median CAR for acquirers in transactions where control is not 
acquired is zero (Table 5, Panel B). A Wilcox-signed-rank test of medians also shows that acquirer returns are significantly higher in transactions where the acquirer gains majority control of the target in comparison to transactions where majority control is not acquired $(\mathrm{p}=0.008)$.

These calculations suggest that the shareholders of developed-market acquirer firms reap substantial dollar value gains from emerging-market acquisitions. The announcement returns translate to an aggregate dollar value gain of \$111.5 billion for shareholders of acquiring firms considering all emerging market targets and \$75.6 billion considering deals where control is transferred to the acquirer. ${ }^{16}$

At first pass, these numbers look anomalously large. The median transaction value in an emerging-market acquisition is $\$ 110.5$ million in transactions where control is acquired (Table 5, Panel A). The median value of the acquirer's stock price reaction suggests a dollar value gain of $\$ 104.6$ million per transaction. ${ }^{17}$ The median net return (acquirer’s dollar value gain/transaction value) on a transaction by transaction basis is 1.37 . If we use averages instead of medians, then the average acquirer gain of $\$ 889.1$ million compares even more favorably to the average transaction value of \$393.6 million. By contrast, the median net return in transactions where minority stakes are acquired is -0.2 (Table 5 , Panel B), suggesting that the transfer of control rights is a key mechanism for generating positive returns for foreign investors in emerging markets. Why does the transfer of ownership to the foreign acquirer drive up its market value by an amount greater than the value of the target acquired?

In part, the huge dollar value gain can be explained by simple mechanics. Acquiring firms are, on average, over thirty times larger than the target firms. The median acquirer market

\footnotetext{
${ }^{16}$ The aggregate dollar value gain is calculated by multiplying the average dollar value gain per transaction ( $\$ 285.8$ million) in Panel C of Table 5 by the number of transactions with available data $(\mathrm{N}=390)$. Similarly, the aggregate dollar value gain in transactions where control is acquired is calculated by multiplying the average dollar value gain per transaction ( $\$ 889.1$ million) by the number of transactions $(\mathrm{N}=85)$ in Panel A of Table 5.

${ }^{17}$ This is the median value of the acquirer dollar value gain calculated by transaction rather than the median CAR times the median market capitalization value for the acquirers in the sample.
} 
capitalization is $\$ 6.8$ billion in transactions where control is acquired (Table 5, Panel A). A small positive cumulative abnormal return translates to a large dollar value gain.

However, the question of why the dollar value gains, elusive in domestic M\&As, are so huge in emerging-market transactions remains. Earlier we argued that the market value of an asset can differ across countries given differences in the know-how, brand value and other intangible firm characteristics as well as the institutional setting that protects property rights. Since a direct benefit of better institutions and property rights enforcement in developed-markets is the legal protection of intangibles such as $R \& D$, we expect any value that is transferred through better institutions from developed- to emerging-market firms to be more pronounced in industries associated with high asset intangibility, i.e., in industries where governance is likely to be most important.

We begin by examining the ability of developed-market acquirers to transfer intangibles such as know-how and brand value to emerging-market targets in greater detail. In the following section, we focus on institutional differences between countries.

\section{Sources of Acquirer Value Gains}

\subsection{Intangible Assets}

Detailed investigation of intangible assets has found that they are often large and have substantial productivity benefits. For example, previous studies have found that the R\&D assets bring benefits in the form of positive marginal product and market valuation (Hall, 1993; Griliches, 1981; and Lev and Sougiannis, 1996). Brynjolofson and Hitt (2003) find that each dollar of capital invested in computer capital results in \$17 of market value in contrast to investments in traditional PP\&E which result in a return of $\$ 0.7$ for every dollar invested. Furthermore, Hausmann and Sturzenegger (2006) argue that a substantial missing component of value from book value estimates of foreign assets acquired (and recorded by the Bureau of 
Economic Analysis) is precisely this value from intangibles assets that firms from developed countries can bring to emerging-market firms.

Consistent with the above arguments, we hypothesize that the transfer of intangibles through an acquisition is likely to be most important in the context of a developed market acquirer and an emerging market target. For instance, the better governance and institutions typically ascribed to the developed markets will promote greater investment in intangibles such as proprietary technologies. In contrast, firms in emerging markets may be reluctant to invest in R\&D in poor property rights environments. Any value gain associated with the transfer of intangible assets may be further compounded if the acquisition results in a transfer (even partial) of the laws and institutions which govern the developed market firms to the emerging market targets.

To test the hypothesis that announcement returns and dollar value gains increase in settings with large intangibles we construct two measures of asset intangibility using industrylevel data from Compustat. The first measure is the median of the sum of advertising and R\&D expenditures normalized by sales for all firms in the U.S. in the same industry as the target and same year as the acquisition announcement. A similar measure also was constructed using data from the acquirer's industry. A second measure was constructed by normalizing the advertising and R\&D expenses by the aggregate market capitalization in the acquirer's and target's industries.

Table 6 presents the results. Columns (1a) and (1b) show that acquirer returns and dollar value gains increase significantly when majority control is acquired in target industries with high values of asset intangibility. Similarly, asset intangibility also has a significant impact on returns and value gains if acquirers come from industries with large intangible assets (Columns (2a) and (2b)). The results continue to hold when advertising and $R \& D$ expenditures are normalized by market capitalization values rather than sales (not reported). 
The relationship between asset intangibility and returns and value gains is significant only when control is transferred. The result suggests that acquirers in industries with significant intangible assets may be more likely to share these assets with target firms in emerging markets (with poor property rights protection) if majority control is acquired.

We interpret the findings related to asset intangibility as being specific to the context of developed market acquirers and emerging market targets. To confirm whether the importance of asset intangibility and the acquisition of control are unique to the emerging market setting, we ran an additional specification with a pooled sample of developed and emerging market targets, but keeping the set of developed market acquirers constant. These results suggest that our finding that control in conjunction with asset intangibility delivers higher acquirer returns is distinctive to emerging market targets (Columns (1c)-(2c), Table 6). We find an insignificant coefficient of the -0.038 for the interaction term of target industry asset intangibility interacted with control suggesting that the relationship between asset intangibility and acquirer returns is not significant when control of a developed market target is acquired. Conversely, the interaction term between target industry asset intangibility, control, and an emerging market target is positive and significant with a coefficient of 0.776 (Column (1c)). A similar pattern of results obtains when we use a measure of acquirer industry intangibility in conjunction with control of an emerging market target (Column (2c)).

In summary, the data suggest that the abnormal announcement returns and dollar value gains are the largest in settings with the largest intangibles, i.e., in industries with high R\&D and brand intensity and when control is acquired. The improved governance that acquiring firms from developed markets can transfer to emerging-market targets is a further source of acquirer gains. This is subject to which we now turn. 


\subsection{Improved Governance}

Legal and institutional features can have an important impact on the property rights setting and the incomplete contracting problem in emerging markets. The ability of developedmarket acquirers to bring better institutions to the emerging-market targets also may drive up expected future cash flows if the target is acquired and becomes bonded to better institutions (Coffee, 1999). We use the legal and institutional measures as proposed by La Porta et. al (1998) for the countries in our sample as proxies for institutional differences between countries. Furthermore, to increase the cross-sectional variation in institutional differences we augment our existing sample of emerging market targets with acquisitions of developed-market targets made by the acquirers in our sample. ${ }^{18}$

Table 7 (Panel A) shows correlation coefficients between various legal and institutional measures as proposed by La Porta et. al (1998) for the target countries in our sample. The correlations between GDP per capita and the efficiency of the judicial system, the risk of expropriation, the rule of law, and the risk of contract repudiation are $0.72,0.86,0.90$, and 0.89 , respectively, indicating that nations with higher GDP are associated with better institutional characteristics. The pattern of correlations suggests that the degree of economic development (measured by GDP per capita) is highly correlated with institutional development. Developedmarket acquisitions of emerging-market firms therefore offer a unique setting to examine value creation across countries with vast asymmetries in institutional settings and economic development. Note that the classification of emerging and developed markets is made on the basis of GDP per capita.

Table 7 (Panel B) presents statistics for the average distance between the institutional environment of the acquirers and the targets, using the augmented sample of emerging- and developed-market targets. The first column shows that, on average, the distance between the

\footnotetext{
${ }^{18}$ To ensure comparability, we restrict the set of acquirers to the initial sample of firms that made acquisitions in emerging-markets. We expand the set of targets to include acquisitions made by these firms of publicly-listed developed-market firms.
} 
institutional environment of developed-market acquirers and developed-market targets is statistically insignificant. The second column shows a striking difference between the institutional environment of developed-market acquirers and emerging-market targets. On average, the distance between the institutional environment of developed-market acquirers and emergingmarket targets is positive and statistically significant. Medians are presented in parentheses and confirm the pattern shown by the means.

Table 7 (Panel C) presents regression results for the impact of a pairing between a developed-market acquirer that ranks above the median while the target (developed or emerging) ranks below the median for a particular dimension of institutional quality on acquirer returns. Acquirers and targets are classified as high or low depending on whether they rank above or below the median for a particular indicator of institutional quality. ${ }^{19}$ For example, Japan has a score of 10, an above median value for the efficacy of the judiciary, while Thailand scores 3.25 or below the median for the same measure. Therefore, a Japanese acquirer would be classified as high and a Thai target as low along this dimension.

The results suggest that developed-market acquirer returns increase when the target country scores below the median (Low) along the rule of law ranking while the acquirer firm belongs to a country that scores above the median (High). The coefficient on the rule of law measure is 0.028 and significant at the $5 \%$ level (Column (1)). While the raw effect of control is insignificant in Column (2), the coefficient on the interaction term between the rule of law measure and the majority control variable is 0.059 (Column (2)) and is statistically significant at the $5 \%$ level. The finding suggests that acquirer returns increase by an additional 5.9\% when the acquirer gains majority control and the rule of law rank for the target country lies below the median value for this institutional quality measure. Similarly, the results also show that that developed-market acquirer returns increase significantly when majority control is acquired and

\footnotetext{
${ }^{19}$ The median value for a given indicator of institutional quality was calculated using the 25 countries in our sample with available data.
} 
the target is from a country with high contract repudiation and expropriation risks (Columns (6) and (8)).

The estimations were also conducted using a distance measure of institutional quality, calculated as the difference between the acquirer and target country scores. For example, Switzerland scores 9.98 for the risk of contract repudiation while the Philippines scores 5.22 along the same institutional quality dimension. The distance between a Swiss acquirer and a Philippine target would therefore be 4.76. Mirroring the pattern in Panel C, the estimations show that if the distance between the rule of law, expropriation risk and contract repudiation risk between the acquirer and the target is high, acquiring control leads to a significant increase in acquirer returns (Table 7, Panel D).

\subsection{Imperfect Capital Markets}

In a world with imperfectly integrated capital markets, the ability of developed-market firms to provide targets in capital-scarce emerging-markets with access to cheaper capital may be a further source of productivity gains associated with M\&A transactions. Consistent with the cost of capital channel, the data supports the view that the ability of developed-market acquirers to provide emerging-market targets with access to international capital markets is significantly related to the acquirer's stock price revaluation and the dollar value gains experienced by the acquiring firm shareholders.

Sovereign bond spreads can be used as a measure for the cost of capital in emerging markets. The estimates include the relative value of the JP Morgan Emerging Market's Bond Index (EMBI) spread as an explanatory variable..$^{20}$ In the sample of emerging market targets, Column (1a) of Table 8 shows that the coefficient estimate for the EMBI spread is positive and

\footnotetext{
${ }^{20}$ The relative value of the EMBI spread was calculated using the EMBI spread for the target country the day the acquisition was announced divided by the average EMBI spread for the target country. The average EMBI spread for the target country was a simple average using the full time series of data available from 1988 to 2002.
} 
significant: As sovereign spreads widen, acquirer returns increase. Dollar value gains also increase as emerging-market spreads widen (Table 8, Column (1b)).

Since bond spreads widen during a crisis we next investigate whether the results we found in Column (1a) reflect the purchase of targets during crisis periods in target nations. We hypothesize that if market values collapse, in the aftermath of the crisis, foreign firms would experience positive returns by acquiring undervalued emerging-market assets. We define a dummy variable, crisis, which assumes the value of 1 if an acquisition is announced three months before the onset of a crisis in the target's nation and up to nine months after. Interestingly, we find in Column (2a) that acquisitions of targets located in crisis nations does not lead to higher acquirer returns as predicted by a fire-sale argument (Krugman, 1998). In unreported results, when we include both variables (EMBI spread and crisis) in the same regression, EMB spread remains significant and the coefficient on crisis remains insignificant. However, these results should be interpreted with caution as we do not find a statistically significant pattern between dollar value gains and EMBI spread as reported in Panel B.

\section{Additional Tests and Robustness Checks}

\subsection{Do Returns for the Acquirers in Our Sample Increase When They Acquire Developed- Market Targets?}

Thus far, in contrast to studies that focus exclusively on data from developed markets, the results in this paper show that the transfer of control from an emerging market target to a developed market acquirer is associated with positive announcement returns for acquiring firms. As a robustness check we confirm that our results regarding control are indeed specific to the emerging market context by examining announcement returns for developed-market acquisitions made by the acquirers in our sample. In particular, we extend the sample to acquisitions of public targets in France, Germany, Japan, United Kingdom, United States, Italy, Spain, Hong Kong, and Singapore. 
Panel A in Table 9 presents the results. Column (1) shows that, in the full set of targets, acquirers now experience negative but statistically insignificant returns in the three-week event window. The results in Column (2) show that when a dummy variable for an emerging-market target is introduced into the regression specification, developed-market acquirers experience a positive and statistically significant increase in returns of $2.3 \%$ when an emerging market target is acquired during a three-week event window.

Column (3) shows that the coefficient on the emerging-market-target dummy variable has a magnitude of 0.032 and continues to be significant when the acquisition of majority control is introduced as an explanatory variable on the right-hand side. However, the coefficient on the CONTROL is negative and statistically insignificant suggesting that when developed-market targets are pooled together with emerging-market targets the acquisition of control per se does not result in positive returns for developed-market acquirers.

In column (4), majority control is interacted with the emerging-market dummy variable. The coefficient on EMERGING MARKET TARGET ${ }^{*}$ CONTROL is 0.066 and is significant at the 5\% level. The result suggests that conditional on the target being in an emerging market, the acquisition of majority control results in positive returns for developed-market acquirers. In column (5), we find consistent results controlling for country fixed effects and the presence of a previous relationship between the acquirer and target. Note that regressions 2-5 control for acquirer firm fixed effects.

In summary, the results in this section suggest that when the sample of cross-border M\&A transactions announced by U.S. acquirers in emerging markets is extended to include M\&A transactions in other developed markets, acquirer returns increase significantly only when the acquisition of an emerging-market target is announced. Furthermore, the evidence suggests the acquisition of majority control of an emerging-market target is the primary driver of acquirer returns and this positive association between acquirer announcement returns and the transfer of majority control is not found when considering developed market targets. 


\subsection{Does the Event Window Matter?}

In this paper, we have focused on a three-week event window given possible information leaks associated with the announcement of an international acquisition. However, much of the earlier work in the finance literature considers smaller event windows. To ensure that our results are robust to alternative definitions of the event window, in Columns (6)-(9) of Table 9, Panel A, we use a 3 day event window. To further ensure comparability with the existing literature we include a number of additional controls used in earlier studies. Finally, since a vast majority of M\&A event studies focus on U.S. data, we limit the sample to U.S. acquirers in Columns (6)-(9).

Once again, we find that developed-market acquirers gain when they announce an acquisition involving the transfer of control of an emerging market (Table 9, Panel A, Column (6)). These results are robust to the inclusion of acquirer and year fixed effects as well as to controls for firm and acquisition characteristics (Table 9, Panel A, Columns (7)-(9)).

\subsection{Are Acquirer Returns Driven by Survivorship Bias?}

Yet another concern is that survivorship bias at the emerging-market target country level drives the positive developed-market acquirer returns that we document in this paper. Survivorship bias could arise if developed country acquirers only make acquisitions in markets where previous transactions have proved to be profitable. To address this problem, we conduct a series of tests. First, note that our emerging-market country sample includes the universe of target countries in East Asia and Latin America where developed-market firms acquired publicly listed targets, where we were able to confirm the existence of a stock price for the target. Second, we include target-country fixed effects in the regression specifications 1-4 in Table 9, Panel B. Acquirer returns continue to be positive and significant with the inclusion of target-country fixed effects.

Third, to test whether the positive acquirer returns in a country are driven by the intensity of developed-market acquisition activity in a target country, we include the number of previous 
transactions in a particular target country as an additional control variable. The coefficient on the variable that measures the number of previous transactions in a target country is positive and significant (Table 9, Panel B, Column (1)). However, the coefficient loses significance when the majority control variable is included in the regression (Table 9, Panel A, Column (2)). Fourth, we construct two variables that measure whether developed-market acquisitions in a target country delivered positive acquirer returns in (i) the year prior to a particular transaction and (ii) two years prior to a particular transaction. The coefficients on the two variables are negative and insignificant (Columns (3) and (4)). The majority control dummy is also positive and significant when it is included in the two regression specifications (not reported). On balance, the results suggest that developed-market acquirer returns continue to be positive and significant when publicly listed emerging market targets are acquired after controlling for factors designed to pick up potential survivorship bias.

\subsection{Additional Tests}

Finally, we provide a series of additional robustness tests. We begin by asking why target-firm shareholders do not capture the surplus value gains as is the case in purely domestic M\&As in the U.S.? Implicit in our results is the suggestion that developed-market firms are in a better bargaining position relative to emerging-market targets. We hypothesize that developedmarket acquirers may have greater bargaining power in emerging-market transactions if fewer bidders compete for targets as compared to the domestic context. As a result, when acquirers from developed markets take over targets in emerging-markets, they may be purchasing relatively illiquid assets that cannot be bought or sold easily. We find a miniscule fraction of transactions report a competing bidder in emerging markets. Therefore, like purchases of private firms or subsidiaries in the domestic context, the valuation of these assets may reflect an illiquidity discount that leads to positive acquirer returns. 
Alternatively, the relative size of developed-market acquirers may put them in a strong bargaining position relative to emerging-market targets. The median market capitalization of developed-market acquirers in our sample is thirty times larger than the median market capitalization of the emerging-market targets. Log values of acquirer- and target-market capitalization are included in the estimations as possible indicators of firm bargaining power-the point estimates are statistically insignificant (not reported). One explanation for the lack of significance for the size variables may be that the relative size of the targets is an order of magnitude less than the acquiring firms. The size variable continues to be insignificant when the relative size of the target is included as an explanatory variable.

In unreported results, acquirer cash is included to pick up possible effects of liquidity provision for the target. We find that there is no significant statistical relationship between acquirer returns and the amount of cash the acquirer has on hand. A caveat to bear in mind is that cash on hand does not provide an indication of the access to cash that the acquiring firm may have.

We also test whether instances of first market entry drive developed-market acquirer returns. Columns (5)-(6) in Table 9, Panel B include dummy variables for previous emergingmarket acquisitions by the acquirer and previous acquisitions in the target's country as additional explanatory variables. ${ }^{21}$ None of these factors drive developed-market acquirer returns in our sample and majority control continues to drive acquirer returns. The estimations also were run without majority control on the right-hand side. The coefficient estimates for measures of first market entry are insignificant.

It is a common assumption that for both the acquirer and target firms to benefit from the synergies that accrue from an acquisition, the two firms must be related in some way (Bradley, Desai, and Kim, 1988; Berger and Ofek, 1995). We include an industry diversification variable to

\footnotetext{
${ }^{21}$ An acquisition is classified as first market entry if, according to the information in SDC, the acquirer made no previous acquisitions in emerging markets or the target's country or region depending on the measure used.
} 
see whether returns are higher when the target and the acquiring firm are in the same two-digit industry. The coefficient estimate is insignificant (Table 9, Panel B, Column (7)). ${ }^{22}$ The coefficient on majority control continues to be significant with the inclusion of the industrial diversification dummy.

Asymmetric information may explain why fewer bidders compete for emerging-market targets. Akin to private targets in the domestic literature, it may be difficult to assess the true value of emerging-market targets. If the target is uncertain about its true stand-alone value, the firm may undervalue its assets so that the acquirer gains. To examine whether developed-market acquirer gains can be linked to the resolution of asymmetric information, in Column (8) (Table 9, Panel B) the acquirer is classified as having a prior relationship with the target if the acquirer had an equity stake in the target before to the acquisition announcement. ${ }^{23}$ The magnitude for the estimate for PREVIOUS RELATIONSHIP*CONTROL is positive but not statistically significant. An explanation for the lack of significance is small sample bias; only 21 transactions in the final sample report a previous relationship between the acquirer and target.

The estimations also were run including various deal and target characteristics reported in the previous literature as determinants of developed-market acquirer returns (not reported). The additional variables tested include whether the target was bankrupt, there was a competing bidder, or an unsolicited bid, the target was a division, the deal was a new joint venture, the target was being privatized, the deal was privately negotiated, and whether the deal was a tender offer. None of these additional variables explain acquirer returns when an emerging-market target is acquired. A variable to capture the impact of the medium of payment was created as the fraction of cash paid in an acquisition relative to the total cash plus equity. The method of payment also proved insignificant in explaining developed-market acquirer returns. However, these results should be

\footnotetext{
${ }^{22}$ Out of 460 transactions where SIC code information was available for both the acquirer and the emerging-market target, 153 transactions are classified as diversifying transactions.

${ }^{23}$ The inclusion of the existence of a prior relationship by itself does not have a statistically significant impact on acquirer announcement period returns.
} 
interpreted with caution since SDC coverage of deal characteristics for transactions involving emerging-market targets is sparse.

\section{Conclusion}

In the FDI and trade literature, capital flows from developed to developing nations are the subject of many studies that focus on productivity spillovers associated with multinational firm activity (Caves, 1996). The international M\&A literature has mainly focused on developedmarket M\&A activity in large part because FDI liberalizations allowing foreign acquisitions into emerging markets did not take place till the late 1980s and early to mid 1990s.

This paper uses abnormal announcement returns associated with M\&A transactions to estimate the market-capitalized returns to FDI in emerging markets. To do so, we examine M\&A transactions that involve publicly-listed developed-market acquirer and emerging-market targets between January 1, 1988, and December 31, 2003. Puzzlingly, in contrast to the previous literature that uses U.S. data, the evidence suggests that, on average, acquirer returns show a statistically significant increase of $1.18 \%$. The market-adjusted announcement returns translate to dollar value gains of $\$ 111.5$ billion. $^{24}$

We find that positive acquirer returns are driven by the acquisition of corporate control. On average, acquirers realize a positive return of $4.43 \%$ when they announce the acquisition of control of a public target from an emerging market. The median transaction value in an emergingmarket acquisition involving the transfer of control is $\$ 110.5$ million. The median acquirer stock price reaction suggests an average dollar value gain of \$104.6 million per transaction. Thus, the median net return (acquirer's dollar value gain/transaction value) is 1.37 when control of an emerging market target is transferred to a developed market acquirer.

By pooling developed- and emerging-markets with geographic segment data, Denis, Denis and Yost (2002) find that global diversification results in average valuation discounts of

\footnotetext{
${ }^{24}$ Distinct from domestic M\&A transactions, the distribution of gains shifts in favor of acquiring firms.
} 
approximately the same magnitude as those for industrial diversification. It appears that looking at the international M\&A data through the emerging-developed market lens as we do in this paper results in positive acquirer returns for transactions that involve control.

We offer a possible explanation for the anomalous acquirer returns in the context of emerging market M\&A. Acquirer returns are found to depend on five factors: the value of intangible assets that can be transferred from acquirer to target, the greater the asymmetry between developed and emerging market institutions, the greater the complementarity between asset intangibility and institutional protection, the greater the cost of capital in the emerging market, and the weaker the bargaining power of the target. We leave open as avenues for future research alternative explanations to resolve the puzzle of positive acquirer returns and dollar value gains in emerging-market M\&As. 


\section{References}

Aitken, Brian and Ann Harrison, 1999. "Do Domestic Firms Benefit from Direct Foreign Investment? Evidence from Venezuela," American Economic Review, 89(3), 605-618.

Andrade, Gregor, Mark L. Mitchell, and Erik Stafford (2001). "New Evidence and Perspectives on Mergers.” Journal of Economic Perspectives, Vol. 15, No. 2, 103-120.

Antras, Pol, Mihir Desai and Fritz Foley (2007). "Multinational Firms, FDI Flows and Imperfect Capital Markets,” NBER Working Paper \# 12855.

Berger, Philip and Eli Ofek "Diversification's Effect on Firm Value," Journal of Financial Economics, 1995, Vol. 37, No. 1, 39-65.

Bradley, Michael, Anand Desai, and E. Han Kim (1988). "Synergistic Gains from Corporate Acquisitions and their Division Between the Stockholders of Target and Acquiring Firms.” Journal of Financial Economics, Vol. 21, No. 1, 3-40.

Bris, Arturo and Christos Cabolis (2006). "The Value of Investor Protection: Evidence from Cross-Border Mergers,” Forthcoming Review of Financial Studies.

Brynjolfsson, Erik and Lorin Hitt (2003). "Computing Productivity: Firm-level Evidence," Review of Economics and Statistics, Vol. 85, No. 4, 793-808

Buiter, Willem (2006). "Dark Matter or Cold Fusion?” Goldman Sachs Global Economics Paper No. 136, 1-16.

Caves, Richard E., 1996. Multinational Enterprise and Economic Analysis, Cambridge University Press: Cambridge, U.K.

Chan, Louis, Josef Lakonishok, and Theodore Sougiannis (2001). "The Stock Market Valuation of Research and Development Expenditures.” Journal of Finance, Vol. 56, 2431-2456.

Coffee, John C. (1999). "The Future as History: The Prospects for Global Convergence in Corporate Governance and its Implications.” Center for Law and Economic Studies, Columbia University School of Law Working Paper No.144.

Coval, Joshua and Erik Stafford (2007). “Asset Fire Sales (And Purchases) in Equity Markets,” Forthcoming, Journal of Financial Economics.

Denis, Diane, David Denis, and Keven Yost (2002). "Global Diversification, Industrial Diversification, and Firm Value,” Journal of Finance Vol. 57, pp. 1951-1979.

Dyck, Alexander and Luigi Zingales (2004). “The Private Benefits of Control.” Journal of Finance, Vol. 59, No. 2, 533-596.

Fuller, Kathleen, Jeffry Netter and Mike Stegemoller, (2002). "What do Returns to Acquiring Firms Tell Us? Evidence from Firms that Make Many Acquisitions, Journal of Finance, Vol. 57, No. 4, 1763-1793. 
Grossman, Sanford and Oliver Hart (1986). "The Costs and Benefits of Ownership: A Theory of Vertical and Lateral Integration.” The Journal of Political Economy, Vol. 94, No. 4, 691719.

Griliches, Zvi (1981). “Market Value, R\&D and Patents,” Economic Letters, Vol. 7, 183-187.

Hall, Brian (1993). “The Stock Market's Valuation of R\&D Investment During the 1980s.” American Economic Review, Vol. 83, No. 2, 259-264.

Hall, Robert (1999). “The Stock Market and Capital Accumulation,” NBER Working Paper No. 7180.

Hart, Oliver (1995). Firms, Contracts, and Financial Structure. Oxford: Oxford University Press.

Hart, Oliver and Moore, John (1990). "Property Rights and the Nature of the Firm," The Journal of Political Economy, Vol. 98, No. 6, 1119-1158.

Hausmann, Ricardo and Federico Sturzenegger (2006). “Global Imbalances or Bad Accounting? The Missing Dark Matter in the Wealth of Nations” CID Working Paper No. 124.

Holmstrom, Bengt and Jean Tirole (1997). "Financial Intermediation, Loanable Funds, and the Real Sector,” Quarterly Journal of Economics, Vol. 112, No. 3, 663-691.

Holmstrom, Bengt and Steven Kaplan (2001). "Corporate Governance and Merger Activity in the United States: Making Sense of the 1980s and 1990s,” Journal of Economic Perspectives, Vol. 15, 121-144

Henry, Peter Blair (2006). “Capital Account Liberalization: Theory, Evidence, and Speculation,” NBER Working Paper No. 12698.

Jovanovic, Boyan and Peter Rousseau (2002). “The q-theory of Mergers,” American Economic Review, Papers and Proceedings Vol. 92, No. 2, 198-204.

Kose, Ayhan, Kose, Eswar Prasad, Kenneth Rogoff and Shang-Jin Wei (2006). "Financial Globalization: A Reappraisal,” NBER Working Paper No. 12384.

La Porta, Rafael, Florencio López-de-Silanes, Andrei Shleifer, and Robert Vishny (1998). "Law and Finance.” Journal of Political Economy, Vol. 106, No. 6, 1113-1155.

Lev, Baruch and Theodore Sougiannis (1996). "The Capitalization, Amortization, and ValueRelevance of R\&D,” Journal of Accounting and Economics, Vol. 21, No. 1, 107-138.

Lipsey, Robert (2007). "Defining and Measuring the Location of FDI Output," NBER Working Paper No. 12996.

Moeller, Sara, Fredrick Schlingeman and Rene Stulz (2005). "Wealth Destruction on a Massive Scale? A Study of Acquiring-Firm Returns in the Recent Merger Wave,” Journal of Finance, Vol. 60, No. 2, 757-782.

Morck, Randall, and Bernard Yeung (1991). "Why Investors Value Multinationality,” Journal of Business, Vol. 64, No. 2, 165-187. 
Morck, Randall, and Bernard Yeung (1992). “Internalization: An Event Study Test,” Journal of International Economics, Vol. 33, 41-56.

Morck, Randall, and Bernard Yeung (2002). "Why Firms Diversify? Internalization versus Agency Behavior" in Hand, John and Baruch Lev, eds., Intangible Assets, Oxford University Press.

Rossi, Stefano and Paolo Volpin (2004). "Cross Country Determinents of Cross-Border Mergers and Acquisitions.” Journal of Financial Economics, forthcoming.

Starks, Laura and Kelsey D. Wei (2004). "Cross-Border Mergers and Differences in Corporate Governance.” Working Paper.

Stulz, Rene (2005). “The Limits of Financial Globalization,” Journal of Finance, Vol. 60, No. 4, 1595-1638. 


\section{Table 1: Number of Transactions by Nation and Industrial Classification}

Notes: The table summarizes the full sample of transactions involving publicly listed developed-market acquirers that made acquisitions of publicly listed emerging and developed market targets by region, sector, and over time for transactions announced between 1988 and 2002. Basic manufacturing are targets with 2-digit SIC codes 20-29; Machinery \& Electronics are targets in SIC codes 30-39; Utilities and Transportation are targets in SIC codes 40-49; Wholesale and Retail Trade are targets in SIC codes 50-59; FIRE are targets in SIC codes 60-69; Tourism and Miscellaneous services are targets in SIC codes 70-89. Data for M\&A transactions, primary SIC codes, and target and acquirer nations is from SDC.

\section{a. By Country}

\section{Emerging-Market Targets}

$\begin{array}{lr}\text { Argentina } & 250 \\ \text { Brazil } & 279 \\ \text { Bolivia } & 6 \\ \text { Chile } & 127 \\ \text { China } & 8 \\ \text { Columbia } & 2 \\ \text { Ecuador } & 1 \\ \text { India } & 51 \\ \text { Indonesia } & 112 \\ \text { Malaysia } & 150 \\ \text { Mexico } & 322 \\ \text { South Korea } & 164 \\ \text { Pakistan } & 1 \\ \text { Peru } & 7 \\ \text { Philippines } & 95 \\ \text { Thailand } & 129 \\ \text { Venezuela } & 4 \\ \text { Total } & \mathbf{1 7 0 8}\end{array}$

b. By Industry

\section{Emerging-Market Targets}

Basic Manufacturing

Machinery \& Electronics

Utilities \& Transportation

Wholesale \& Retail Trade

Financial Services (FIRE)

Tourism \& Misc. Services

Other

Total
Developed-Market Targets

Canada

France

6 Germany

127 Hong Kong

8 Italy

2 Japan

1 Netherlands

51 Singapore

112 Spain

150 United Kingdom

322 United States

164 Total

1

7

95

129

1,708

\section{$\underline{\text { Developed-Market Targets }}$}

288
Basic Manufacturing

Machinery \& Electronics

Utilities \& Transportation

Wholesale \& Retail Trade

Financial Services (FIRE)

Tourism \& Misc. Services

Other

Total
Developed-Market Acquirers

$\begin{array}{rlr}55 & \text { Canada } & 176 \\ 38 & \text { France } & 111 \\ 57 & \text { Germany } & 54 \\ 12 & \text { Hong Kong } & 49 \\ 37 & \text { Italy } & 21 \\ 38 & \text { Japan } & 111 \\ 15 & \text { Netherlands } & 52 \\ 3 & \text { Singapore } & 139 \\ 14 & \text { Spain } & 80 \\ 92 & \text { United Kingdom } & 118 \\ 1,088 & \text { United States } & 2,246 \\ \mathbf{1 , 4 4 9} & \text { Total } & \mathbf{3 , 1 5 7}\end{array}$

Developed-Market Acquirers

262

Basic Manufacturing

609

406 Machinery \& Electronics 866

118 Utilities \& Transportation 269

91 Wholesale \& Retail Trade 142

154 Financial Services (FIRE) 503

376 Tourism \& Misc. Services 298

42 Other 470

1,449 Total 3,157 
Table 2: Pre- and Post-Acquisition Ownership by Target Region

Notes: The table summarizes mergers and acquisitions involving publicly listed developed-market acquirers and a publicly listed targets by pre- and post-acquisition ownership across emerging and developed markets. The table covers all M\&A transactions announced between 1988 and 2003 and for which ownership data is available. Emerging markets include Argentina, Brazil, Bolivia, Chile, China, Columbia, Ecuador, India, Indonesia, Malaysia, Mexico, Pakistan, Peru, Philippines, South Korea, Thailand and Venezuela. Developed markets include Canada, France, Germany, Hong Kong, Italy, Japan, Netherlands, Singapore, Spain, the United Kingdom, and the United States. The developed-market target sample is restricted to developed-market acquirers who also engaged in emerging market transactions. M\&A transactions are identified and control information is collected from SDC data items "Percent Shares Acquired" and "Percent Shares Owned after Transaction." Ownership information is available for 1051 observations in emerging markets and 882 observations in developed markets.

Panel A: Emerging-Market Targets

\begin{tabular}{|c|c|c|c|c|c|c|}
\hline \multirow{2}{*}{$\begin{array}{l}\text { Number of M\&A transactions } \\
\text { Post-Acquisition Ownership }\end{array}$} & \multicolumn{2}{|c|}{$\begin{array}{c}\text { Acquirer Had Minority } \\
\text { Interest Before } \\
\text { Acquisition } \\
\end{array}$} & \multicolumn{4}{|c|}{ Pre-Acquisition Ownership } \\
\hline & No & Yes & $<20 \%$ & $20-40 \%$ & $40-50 \%$ & $50 \%+$ \\
\hline $0-50 \%$ & 233 & 19 & 9 & 8 & 2 & 0 \\
\hline $51-95 \%$ & 144 & 56 & 5 & 11 & 8 & 32 \\
\hline $95-100 \%$ & 491 & 108 & 1 & 3 & 9 & 95 \\
\hline Total & 868 & 183 & 15 & 22 & 19 & 127 \\
\hline
\end{tabular}

Panel B: Developed-Market Targets

\begin{tabular}{|c|c|c|c|c|c|c|}
\hline Number of M\&A transactions & $\begin{array}{r}\text { Acquire } \\
\text { Inte } \\
\mathrm{Ac} \\
\end{array}$ & $\begin{array}{l}\text { Minority } \\
\text { fore } \\
\text { on } \\
\end{array}$ & & re-Acquis & on Owner & \\
\hline$\underline{\text { Post-Acquisition Ownership }}$ & No & Yes & $<20 \%$ & $20-40 \%$ & $40-50 \%$ & $50 \%+$ \\
\hline $0-50 \%$ & 141 & 41 & 39 & 1 & 1 & 0 \\
\hline $51-95 \%$ & 12 & 8 & 0 & 2 & 3 & 3 \\
\hline $95-100 \%$ & 637 & 43 & 3 & 4 & 16 & 20 \\
\hline Total & $\begin{array}{l}790 \\
\end{array}$ & 92 & 42 & 7 & 20 & 23 \\
\hline
\end{tabular}




\section{Table 3: Acquirer Returns, Target Returns, Joint Returns}

Notes: This table summarizes average stock market reactions to the announcement of M\&A transctions involving publicly listed (i) developed-market acquirers; (ii) emerging market targets and (iii) developed-market targets. The developedmarket target sample is restricted to acquisitions made by devloped-market acquirers who also made emerging-market acquisitions. Panels A and B show summary statistics for developed-market acquirer and emerging market target returns, respectively, for different subsamples of transactions. Panel C presents market-capitalization weighted joint returns for the emerging market target sample. Panels D presents market-capitalization values for developed-market acquirers and emerging-market targets. The event window comprises a symmetric 3-week period. Averages are reported in standardized monthly return units. Returns are calculated using continuous compounding of the percent changes in the weekly equity closing prices (equivalent to a "buy and hold" methodology). Raw returns are unadjusted average returns. CARs are calculated using the market model. Market adjusted returns are raw returns minus the market return. *, **, and *** denote statistical significance at the $10 \%, 5 \%$, and $1 \%$ levels, respectively.

\section{A. Developed-Market Acquirer Returns}

\section{A1. Emerging Market Target}

\begin{tabular}{|c|c|c|c|}
\hline Local Currency & a. All EM Targets & b. Acquirer Gains Control & c. Acquirer Does Not Gain Control \\
\hline Returns & Raw Returns & Raw Returns & $\underline{\text { Raw Returns }}$ \\
\hline$\overline{-1:+1(\text { Mean })}$ & $2.31 \% * * *$ & $4.43 \% * * *$ & $-0.05 \%$ \\
\hline$-1:+1$ (Median) & $0.88 \% * *$ & $3.97 \% * * *$ & $0 \%$ \\
\hline$N$ & 415 & 92 & 178 \\
\hline
\end{tabular}

A2. Developed Market Target

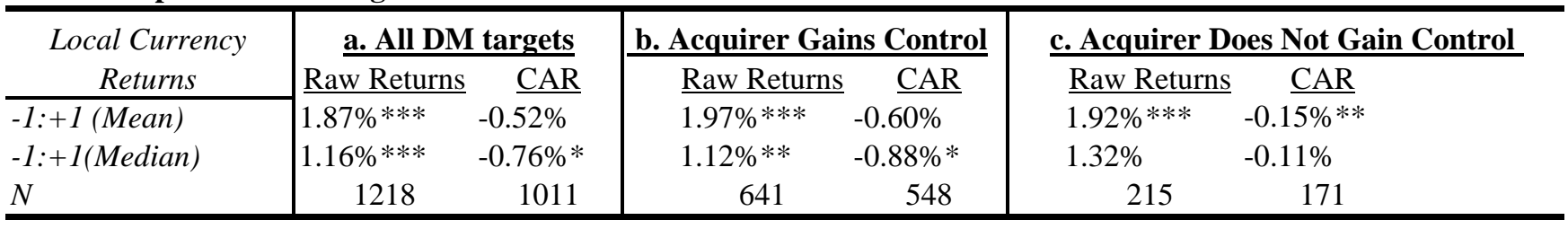

B. Emerging Market Target Returns

\begin{tabular}{|c|c|c|c|}
\hline Local Curr & a. All EM Targets & b. Acquirer Gains Control & c. Acquirer Does Not Gain Control \\
\hline Returns & Raw Returns Mkt Adj & 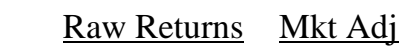 & $\underline{\text { Raw Returns }}$ Mkt Adj \\
\hline$\overline{-1:+1(\text { Mean) }}$ & $6.49 \% * * *$ & $9.03 \% * * *$ & $4.33 \% *$ \\
\hline$-1:+1$ (Median) & $2.74 \% * * *$ & $3.47 \% * *$ & $2.55 \% * *$ \\
\hline$N$ & 334 & 67 & 142 \\
\hline
\end{tabular}

C. Market-Capitalization Weighted Joint Returns in Emerging Markets

\begin{tabular}{|c|c|c|c|c|}
\hline & a. All EM T & Targets & b. Acquirer Gains Control & c. Acquirer Does Not Gain Control \\
\hline U.S. Dollar Returns & Raw Returns & Mkt Adj & $\underline{\text { Raw Returns }} \underline{\text { Mkt Adj }}$ & $\underline{\text { Raw Returns }} \underline{\text { Mkt Adj }}$ \\
\hline -1:+1(Mean) & $1.84 \% * *$ & $1.24 \%$ & $5.61 \% * * *$ & $-1.29 \%$ \\
\hline$-1:+1$ (Median) & $0.87 \% *$ & $0.86 \%$ & $5.63 \% * * *$ & $-1.09 \%$ \\
\hline$N$ & 239 & 236 & 41 & 108 \\
\hline
\end{tabular}

D. Market Capitalization Values

\begin{tabular}{l|c|c}
\hline \hline & Developed-Market Acquirer & Emerging-Market Target \\
Mean & \$40.59 Billion & $\$ 835.22$ Million \\
Median & \$16.98 Billion & $\$ 165.44$ Million \\
\hline
\end{tabular}


Table 4: Majority Control Is a Key Feature of Transactions with Positive Acquirer Returns

Notes: This table summarizes the results of regressions where the dependent variable is abnormal returns for acquirer firms during a 3-week event window around the announcement date on characteristics of the involved firms. All M\&A transactions in the sample involve a public acquirer from a developed market and a public target from an emerging market between 1988-2003. Emerging markets include Argentina, Brazil, Bolivia, Chile, China, Columbia, Ecuador, India, Indonesia, Malaysia, Mexico, Pakistan, Peru, Philippines, South Korea, Thailand and Venezuela. Developed markets include Canada, France, Germany, Hong Kong, Italy, Japan, Netherlands, Singapore, Spain, the United Kingdom, and the United States. Weekly abnormal returns are calculated using a market model and are continuously compounded, then standardized to monthly units. The acquisition of control is a dummy variable identified if the acquirer holds $50 \%$ or more of the target firm's equity following the acquisition and did not previously have control. Mean coefficient estimates are reported with robust standard errors in parentheses. *, **, and ${ }^{* * *}$ denote statistical significance at the $10 \%, 5 \%$, and $1 \%$ levels.

\begin{tabular}{|c|c|c|c|c|c|c|c|c|}
\hline & 1 & 2 & 3 & 4 & 5 & 6 & 7 & 8 \\
\hline Intercept & $\begin{array}{l}0.012^{*} \\
(0.007)\end{array}$ & $\begin{array}{l}-0.017^{*} \\
(0.009)\end{array}$ & $\begin{array}{l}-0.002 \\
(0.007)\end{array}$ & $\begin{array}{r}-0.029 \\
(0.032)\end{array}$ & $\begin{array}{l}-0.027 \\
(0.032)\end{array}$ & $\begin{array}{c}0.010 \\
(0.034)\end{array}$ & $\begin{array}{l}-0.019 \\
(0.032)\end{array}$ & $\begin{array}{l}-0.012 \\
(0.031)\end{array}$ \\
\hline Announced b/w1996-2002 & & $\begin{array}{l}0.034 * * * \\
(0.011)\end{array}$ & & $\begin{array}{c}0.018 \\
(0.014)\end{array}$ & & & & \\
\hline Control & & & $\begin{array}{c}0.046 * * * \\
(0.015)\end{array}$ & $\begin{array}{l}0.048 * * * \\
(0.016)\end{array}$ & & $\begin{array}{l}0.054 * * \\
(0.027)\end{array}$ & & $\begin{array}{l}0.052 * * * \\
(0.020)\end{array}$ \\
\hline $\begin{array}{l}\text { Post-Acquisition Ownership } \\
(x \%)\end{array}$ & & & & & $\begin{array}{l}0.000^{* *} \\
(0.000)\end{array}$ & $\begin{array}{l}-0.000 \\
(0.000)\end{array}$ & & \\
\hline $\begin{array}{l}\text { Post-Acquisition Ownership } \\
(50 \%<x<90 \%)\end{array}$ & & & & & & & $\begin{array}{c}0.054 * * * \\
(0.020)\end{array}$ & \\
\hline $\begin{array}{l}\text { Post-Acquisition Ownership } \\
(x>90 \%)\end{array}$ & & & & & & & $\begin{array}{r}0.037 * \\
(0.021)\end{array}$ & $\begin{array}{l}-0.006 \\
(0.024)\end{array}$ \\
\hline Target Country Fixed Effects & No & No & No & Yes & Yes & Yes & Yes & Yes \\
\hline $\begin{array}{l}R \text {-squared } \\
N\end{array}$ & $\begin{array}{l}0.00 \\
415\end{array}$ & $\begin{array}{c}0.007 \\
415\end{array}$ & $\begin{array}{l}0.04 \\
254\end{array}$ & $\begin{array}{l}0.10 \\
254\end{array}$ & $\begin{array}{l}0.08 \\
254\end{array}$ & $\begin{array}{l}0.10 \\
254\end{array}$ & $\begin{array}{l}0.10 \\
254\end{array}$ & $\begin{array}{l}0.10 \\
254\end{array}$ \\
\hline
\end{tabular}


Table 5: Summary Statistics for Developed-Market Acquirer Firm Value Gains

Notes: This table presents summary statistics for the shareholder value gains from the announcement of M\&A transctions involving publicly listed (i) developed-market acquirers and (ii) emerging market targets. Panels A, B, and $\mathrm{C}$ show summary statistics for developed-market acquirer returns and acquirer characteristics for different subsamples of transactions. CAR is the is abnormal return for acquirer firms during a 3-week event window around the transaction announcement date. Shareholder dollar value gains are calculated on a transaction by transaction basis by multiplying CARs by the acquirer market capitalization. Net returns also are calculated on a transaction by transaction basis by dividing the dollar value gain by the dollar transaction value.

Developed-Market Acquirer Gains Majority Control

\begin{tabular}{|c|c|c|c|c|c|c|}
\hline Panel A & CAR & $\begin{array}{r}\text { Acquirer } \\
\text { Market } \\
\text { Capitalization } \\
\text { (\$ million })\end{array}$ & $\begin{array}{r}\text { Dollar Value } \\
\text { Gain per } \\
\text { Transaction } \\
\text { (\$ million) }\end{array}$ & $\begin{array}{r}\text { Transaction } \\
\text { Value } \\
\text { (\$ million) }\end{array}$ & $\begin{array}{r}\text { Target Market } \\
\text { Capitalization } \\
\text { (\$ million) }\end{array}$ & $\begin{array}{l}\text { Net Return per } \\
\text { Transaction }\end{array}$ \\
\hline Mean & 0.044 & 29719.00 & 889.13 & 393.55 & 734.54 & $\overline{7794.29}$ \\
\hline Median & 0.040 & 6844.20 & 104.63 & 110.54 & 144.72 & 1.37 \\
\hline Top Quartile & 0.105 & 39303.30 & 850.19 & 325.04 & 434.13 & 8.21 \\
\hline Bottom Quartile & -0.033 & 2707.26 & -217.59 & 33.50 & 26.48 & -1.09 \\
\hline Skewness & 0.926 & 2.53 & 5.26 & 7.19 & 4.95 & 7.46 \\
\hline$N=87$ & & & & & & \\
\hline \multicolumn{7}{|c|}{ Developed-Market Acquirer Does Not Gain Control } \\
\hline Panel B & CAR & $\begin{array}{r}\text { Acquirer } \\
\text { Market } \\
\text { Capitalization } \\
\text { (\$ million) }\end{array}$ & $\begin{array}{r}\text { Dollar Value } \\
\text { Gain per } \\
\text { Transaction } \\
\text { (\$ million) }\end{array}$ & $\begin{array}{r}\text { Transaction } \\
\text { Value } \\
\text { (\$ million) }\end{array}$ & $\begin{array}{r}\text { Target Market } \\
\text { Capitalization } \\
(\$ \text { million })\end{array}$ & $\begin{array}{r}\text { Net Return per } \\
\text { Transaction }\end{array}$ \\
\hline Mean & -0.002 & 51754.74 & -147.37 & 185.50 & 896.60 & 649.23 \\
\hline Median & 0.000 & 26830.69 & -3.41 & 52.48 & 294.77 & -0.20 \\
\hline Top Quartile & 0.053 & 55378.89 & 673.68 & 174.00 & 972.21 & 9.02 \\
\hline Bottom Quartile & -0.057 & 8017.07 & -381.85 & 19.12 & 61.91 & -7.77 \\
\hline $\begin{array}{r}\text { Skewness } \\
N=167\end{array}$ & -0.453 & 4.24 & 1.51 & 5.34 & 4.64 & 10.59 \\
\hline
\end{tabular}

Full Sample

\begin{tabular}{|c|c|c|c|c|c|c|}
\hline Panel C & CAR & $\begin{array}{r}\text { Acquirer } \\
\text { Market } \\
\text { Capitalization } \\
\text { (\$ million })\end{array}$ & $\begin{array}{r}\text { Dollar Value } \\
\text { Gain per } \\
\text { Transaction } \\
\text { (\$ million) }\end{array}$ & $\begin{array}{r}\text { Transaction } \\
\text { Value } \\
\text { (\$ million) }\end{array}$ & $\begin{array}{r}\text { Target Market } \\
\text { Capitalization } \\
(\$ \text { million })\end{array}$ & $\begin{array}{r}\text { Net Return per } \\
\text { Transaction }\end{array}$ \\
\hline Mean & 0.012 & 40593.11 & 285.78 & 245.05 & 835.22 & 938.20 \\
\hline Median & 0.001 & 16984.64 & 5.17 & 62.50 & 165.44 & 0.12 \\
\hline Top Quartile & 0.070 & 54537.61 & 673.68 & 194.99 & 813.87 & 7.27 \\
\hline Bottom Quartile & -0.056 & 3700.75 & -323.05 & 19.70 & 54.28 & -4.96 \\
\hline $\begin{array}{r}\text { Skewness } \\
N=415\end{array}$ & 0.804 & 4.24 & 4.26 & 9.41 & 4.71 & 9.89 \\
\hline
\end{tabular}


Table 6: Sources of Acquirer Value Gains: Intangible Assets

Notes: The dependent variable is abnormal returns for acquirers in Panel A and Panel C and winsorized log-transformed dollar value gains to target size in Panel B between 1988-2003. All M\&A transactions in Panel A \& B involve a public acquirer from a developed market and a public target from an emerging market. Panel C uses a sample of targets from both emerging markets and developed markets. Weekly abnormal returns are calculated using a market model and are continuously compounded, then standardized to monthly units. Dollar value gains to target size are calcuated as acquirer returns mutltiplied by acquirer market capitalization and normalized by the size of the target firm. This value is log-transformed and winsorized. Control is a dummy variable which takes the value of 1 if the acquirer holds $50 \%$ or more of the target firm's equity following the acquisition and did not previously have control. Asset Intangibility/Sales (Target Ind.) and Asset Intangibility/Sales (Acquirer Ind.) are the median sum of advertising and R\&D expenditures normalized by sales for all firms in the US with the same industry and same year as the acquisition announcement. Mean coefficient estimates are reported with robust standard errors in parentheses. * ${ }^{* *}$, and $* * *$ denote statistical significance at the $10 \%, 5 \%$, and $1 \%$ levels.

\begin{tabular}{|c|c|c|c|c|c|c|}
\hline & \multicolumn{2}{|c|}{$\begin{array}{c}\text { Panel A: Acquirer } \\
\text { Returns, Emerging } \\
\text { Market Targets } \\
\end{array}$} & \multicolumn{2}{|c|}{$\begin{array}{c}\text { Panel B: Dollar Value } \\
\text { Gains, Emerging } \\
\text { Market Targets } \\
\end{array}$} & \multicolumn{2}{|c|}{$\begin{array}{c}\text { Panel C: Acquirer } \\
\text { Returns, All Targets }\end{array}$} \\
\hline & 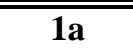 & $\overline{2 a}$ & $\overline{12 b}$ & $\overline{2 \mathbf{2 b}}$ & 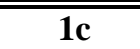 & 2c \\
\hline Control & $\begin{array}{c}0.033^{* *} \\
(0.017)\end{array}$ & $\begin{array}{l}0.029 * \\
(0.016)\end{array}$ & $\begin{array}{l}0.019 * \\
(0.011)\end{array}$ & $\begin{array}{c}0.014 \\
(0.011)\end{array}$ & $\begin{array}{l}-0.002 \\
(0.015)\end{array}$ & $\begin{array}{l}-.005 \\
(0.018)\end{array}$ \\
\hline $\begin{array}{l}\text { Asset Intangibility/Sales } \\
\text { (Target Ind.) }\end{array}$ & $\begin{array}{l}-0.432 \\
(0.325)\end{array}$ & & $\begin{array}{l}-0.136 \\
(0.089)\end{array}$ & & $\begin{array}{l}-0.118 \\
(0.186)\end{array}$ & \\
\hline $\begin{array}{l}\text { Asset Intangibility/Sales* } \\
\text { Control (Target Ind.) }\end{array}$ & $\begin{array}{l}0.738^{*} \\
(0.395)\end{array}$ & & $\begin{array}{l}0.374^{*} \\
(0.214)\end{array}$ & & $\begin{array}{l}-0.038 \\
(0.232)\end{array}$ & \\
\hline $\begin{array}{l}\text { Asset Intangibility/Sales } \\
\text { (Acquirer Ind.) }\end{array}$ & & $\begin{array}{l}-0.357 \\
(0.259)\end{array}$ & & $\begin{array}{c}-0.129 \\
(0.068)^{*}\end{array}$ & & $\begin{array}{l}-0.135 \\
(0.155)\end{array}$ \\
\hline $\begin{array}{l}\text { Asset Intangibility/Sales* } \\
\text { Control (Acquirer Ind.) }\end{array}$ & & $\begin{array}{l}0.798 * * \\
(0.361)\end{array}$ & & $\begin{array}{l}0.528 * * * \\
(0.208)\end{array}$ & & $\begin{array}{c}0.009 \\
(0.209)\end{array}$ \\
\hline Emerging-Market Target & & & & & $\begin{array}{l}-0.002 \\
(0.014)\end{array}$ & $\begin{array}{l}-0.007 \\
(0.015)\end{array}$ \\
\hline Emerging-Market & & & & & 0.036 & 0.034 \\
\hline $\begin{array}{l}\text { Target*Control } \\
\text { Asset Intangibility/Sales }\end{array}$ & & & & & $(0.023)$ & $(0.024)$ \\
\hline (Target Ind.) *Emerging- & & & & & -0.314 & \\
\hline $\begin{array}{l}\text { Market Target } \\
\text { Asset Intangibility/Sales }\end{array}$ & & & & & $(0.373)$ & \\
\hline (Target Ind.) *Emerging- & & & & & $0.776^{*}$ & \\
\hline $\begin{array}{l}\text { Market Target * Control } \\
\text { Asset Intangibility/Sales }\end{array}$ & & & & & $(0.457)$ & \\
\hline $\begin{array}{l}\text { (Acquirer Ind.) *Emerging- } \\
\text { Market Target }\end{array}$ & & & & & & $\begin{array}{l}-0.222 \\
(0.301)\end{array}$ \\
\hline $\begin{array}{l}\text { Asset Intangibility/Sales } \\
\text { (Acquirer Ind.) }{ }^{*} \text { Emerging- } \\
\text { Market Target * Control }\end{array}$ & & & & & & $\begin{array}{c}0.789 * \\
(0.416)\end{array}$ \\
\hline Intercept & $\begin{array}{c}0.002 \\
(0.007)\end{array}$ & $\begin{array}{l}-0.000 \\
(0.008)\end{array}$ & $\begin{array}{c}5.702^{* * *} \\
(0.004)\end{array}$ & $\begin{array}{l}5.703^{* * *} \\
(0.004)\end{array}$ & $\begin{array}{c}0.004 \\
(0.011)\end{array}$ & $\begin{array}{c}0.007 \\
(0.012)\end{array}$ \\
\hline$N$ & 253 & 240 & 171 & 165 & 965 & 965 \\
\hline$R$-squared & 0.0647 & 0.0839 & 0.0778 & 0.1025 & 0.1577 & 0.1579 \\
\hline
\end{tabular}


Table 7 (Panel A): Correlation Coefficient Matrix Between Corporate Governance Measures and Target Characteristics

Notes: This table shows correlation coefficients between target characteristics and various legal and institutional measures as proposed by LLSV (1998) for the countries in our sample. All M\&A transactions in the sample involve a public acquirer from a developed market and a public target from either an emerging market or a developed market. The first column presents correlations between target GDP per capita and insitutional variables. The second column presents correlations between emerging-market targets and the insitutional variables. The third column presents correlations between control being acquired in a transaction and the insitutional quality of the target nation. ${ }^{* * *}, * *$, and $*$ represent 1,5 , and $10 \%$ levels of significance.

\begin{tabular}{lccc}
\hline Correlation Coefficients & Target GDP & $\begin{array}{c}\text { Emerging- } \\
\text { Market Target }\end{array}$ & $\begin{array}{c}\text { Control } \\
\text { Acquired }\end{array}$ \\
\hline \hline Rule of Law & $0.904^{* * *}$ & $-0.925^{* * *}$ & $0.371^{* * *}$ \\
Efficacy of Judiciary & $0.721^{* * *}$ & $-0.821^{* * *}$ & $0.341^{* * *}$ \\
Contract Repudiation Risk & $0.896^{* * *}$ & $-0.873^{* * *}$ & $0.364^{* * *}$ \\
Expropriation Risk & $0.855^{* * *}$ & $-0.909^{* * *}$ & $0.375^{* * *}$ \\
\hline
\end{tabular}

Table 7 (Panel B): Corporate Governance Distance Between DevelopedMarket Acquirers and Targets

Notes: This tables shows the corporate governance distance between the developed-market acquirers and targets in emerging and developed markets. All M\&A transactions in the sample involve a public acquirer from a developed market and a public target from either an emerging market or a developed market. Average values are shown with median values in parentheses. The higher the number the greater corporate governance distance between the acquirer and target. ***, **, and * represent 1,5 , and $10 \%$ levels of significance.

\begin{tabular}{lccc}
\hline $\begin{array}{l}\text { Corporate Governance } \\
\text { Distance between Acquirer } \\
\text { and Target }\end{array}$ & $\begin{array}{c}\text { Developed- } \\
\text { Market Target } \\
\text { (a) }\end{array}$ & $\begin{array}{c}\text { Emerging- } \\
\text { Market Target } \\
\text { (b) }\end{array}$ & $\begin{array}{c}\text { T-test of } \\
\text { Difference } \\
\text { (a)-(b) }\end{array}$ \\
\hline \hline Rule of Law & 0.283 & 3.968 & Yes*** \\
& $(0.000)$ & $(3.750)$ & \\
Efficacy of Judiciary & 0.264 & 3.311 & Yes*** \\
& $(0.000)$ & $(3.250)$ & \\
Contract Repudiation Risk & 0.071 & 2.579 & Yes*** \\
& $(0.000)$ & $(2.830)$ & \\
Expropriation Risk & 0.020 & 2.287 & Yes*** \\
\hline
\end{tabular}


Table 7 (Panel C): Sources of Acquirer Value Gains-Improved Governance (Measure 1)

Notes: This table summarizes the results of regressions where the dependent variable is abnormal returns for acquirer firms during a 3-week event window around the announcement date on characteristics of the involved firms. All M\&A transactions in the sample involve a public acquirer from a developed market and a public target from either an emerging market or a developed market. Weekly abnormal returns are calculated using a market model and are continuously compounded, then standardized to monthly units. Acquirers and targets are classified as High or Low depending on whether they rank above or below the median for a particular indicator of instituional quality. The table presents regression results for the impact of a pairing between a developed-market acquirer that ranks high and a target that ranks low on a particular dimesion of instituional quality on acquirer returns. The institutional quality rankings are from LLSV (1998). Control is a dummy which takes on a value of one if majority control is acquired in a transaction. Mean coefficient estimates are reported with robust standard errors in parentheses. ${ }^{*}, * *$, and ${ }^{* * *}$ denote statistical significance at the $10 \%, 5 \%$, and $1 \%$ levels.

\begin{tabular}{|c|c|c|c|c|c|c|c|c|}
\hline & 1 & 2 & 3 & 4 & 5 & 6 & 7 & 8 \\
\hline Rule of Law & $\begin{array}{c}0.028 * * \\
(0.014)\end{array}$ & $\begin{array}{c}0.011 \\
(0.019)\end{array}$ & & & & & & \\
\hline Control & & $\begin{array}{l}-0.008 \\
(0.013)\end{array}$ & & $\begin{array}{l}-0.003 \\
(0.014)\end{array}$ & & $\begin{array}{r}-0.011 \\
(0.013)\end{array}$ & & $\begin{array}{l}-0.012 \\
(0.013)\end{array}$ \\
\hline $\begin{array}{l}\text { Rule of } \\
\text { Law*Control }\end{array}$ & & $\begin{array}{l}0.059 * * \\
(0.029)\end{array}$ & & & & & & \\
\hline $\begin{array}{l}\text { Efficacy of } \\
\text { Judiciary }\end{array}$ & & & $\begin{array}{l}0.024^{*} \\
(0.014)\end{array}$ & $\begin{array}{c}0.013 \\
(0.025)\end{array}$ & & & & \\
\hline $\begin{array}{l}\text { Efficacy of } \\
\text { Judiciary*Control }\end{array}$ & & & & $\begin{array}{c}0.017 \\
(0.027)\end{array}$ & & & & \\
\hline $\begin{array}{l}\text { Contract } \\
\text { Repudiation Risk } \\
\text { Contract }\end{array}$ & & & & & $\begin{array}{c}0.012 \\
(0.017)\end{array}$ & $\begin{array}{l}-0.008 \\
(0.021)\end{array}$ & & \\
\hline $\begin{array}{l}\text { Repudiation } \\
\text { Risk*Control }\end{array}$ & & & & & & $\begin{array}{c}0.076^{* * *} \\
(0.029)\end{array}$ & & \\
\hline Expropriation Risk & & & & & & & $\begin{array}{c}0.007 \\
(0.016)\end{array}$ & $\begin{array}{l}-0.010 \\
(0.021)\end{array}$ \\
\hline $\begin{array}{l}\text { Expropriation Risk* } \\
\text { Control }\end{array}$ & & & & & & & & $\begin{array}{c}0.080 * * * \\
(0.029)\end{array}$ \\
\hline $\begin{array}{l}\text { Acquirer Firm } \\
\text { Fixed Effects }\end{array}$ & Yes & Yes & Yes & Yes & Yes & Yes & Yes & Yes \\
\hline $\begin{array}{l}R \text {-squared } \\
N\end{array}$ & $\begin{array}{l}0.207 \\
1414\end{array}$ & $\begin{array}{c}0.352 \\
963\end{array}$ & $\begin{array}{l}0.206 \\
1414\end{array}$ & $\begin{array}{c}0.347 \\
963\end{array}$ & $\begin{array}{l}0.205 \\
1414\end{array}$ & $\begin{array}{c}0.351 \\
963\end{array}$ & $\begin{array}{l}0.204 \\
1414\end{array}$ & $\begin{array}{c}0.352 \\
963\end{array}$ \\
\hline
\end{tabular}




\section{Table 7 (Panel D): Sources of Acquirer Value Gains-Improved Governance (Measure 2)}

Notes: This table summarizes the results of regressions where the dependent variable is abnormal returns for acquirer firms during a 3-week event window around the announcement date on characteristics of the involved firms. All M\&A transactions in the sample involve a public acquirer from a developed market and a public target from either an emerging market or a developed market. Weekly abnormal returns are calculated using a market model and are continuously compounded, then standardized to monthly units. The instituional quality measure is a continuous variable that measures the distance between the acquirer country score and the target country score along a particular dimension of institutional quality. The institutional quality rankings are from LLSV (1998). Control is a dummy which takes on a value of one if majority control is acquired in a transaction. *, **, and *** denote statistical significance at the $10 \%, 5 \%$, and $1 \%$ levels, respectively.

\begin{tabular}{|c|c|c|c|c|c|c|c|c|}
\hline & 1 & 2 & 3 & 4 & 5 & 6 & 7 & 8 \\
\hline Rule of Law & $\begin{array}{c}0.004 \\
(0.003)\end{array}$ & $\begin{array}{l}-0.001 \\
(0.004)\end{array}$ & & & & & & \\
\hline Control & & $\begin{array}{l}-0.012 \\
(0.015)\end{array}$ & & $\begin{array}{c}0.007 \\
(0.014)\end{array}$ & & $\begin{array}{l}-0.013 \\
(0.014)\end{array}$ & & $\begin{array}{l}-0.012 \\
(0.014)\end{array}$ \\
\hline Rule of Law*Control & & $\begin{array}{l}0.012^{*} \\
(0.007)\end{array}$ & & & & & & \\
\hline Efficacy of Judiciary & & & $\begin{array}{l}0.005^{*} \\
(0.003)\end{array}$ & $\begin{array}{c}0.002 \\
(0.004)\end{array}$ & & & & \\
\hline $\begin{array}{l}\text { Efficacy of } \\
\text { Judiciary*Control }\end{array}$ & & & & $\begin{array}{c}0.007 \\
(0.007)\end{array}$ & & & & \\
\hline Contract Repudiation Risk & & & & & $\begin{array}{c}0.006 \\
(0.005)\end{array}$ & $\begin{array}{l}-0.001 \\
(0.006)\end{array}$ & & \\
\hline $\begin{array}{l}\text { Contract Repudiation } \\
\text { Risk*Control }\end{array}$ & & & & & & $\begin{array}{c}0.023^{* * *} \\
(0.009)\end{array}$ & & \\
\hline Expropriation Risk & & & & & & & $\begin{array}{r}0.008 \\
(0.008)\end{array}$ & $\begin{array}{l}-0.001 \\
(0.008)\end{array}$ \\
\hline $\begin{array}{l}\text { Expropriation Risk* } \\
\text { Control }\end{array}$ & & & & & & & & $\begin{array}{l}0.027 * * \\
(0.011)\end{array}$ \\
\hline Acquirer Firm Fixed Effects & Yes & Yes & Yes & Yes & Yes & Yes & Yes & Yes \\
\hline$R$-squared & 0.206 & 0.35 & 0.206 & 0.348 & 0.205 & 0.353 & 0.205 & 0.352 \\
\hline$N$ & 1414 & 963 & 1414 & 963 & 1414 & 963 & 1414 & 963 \\
\hline
\end{tabular}


Table 8: Sources of Acquirer Value Gains: Imperfect

\section{Capital Markets}

Notes: This table summarizes the results of regressions where the dependent variable is abnormal returns for acquirers during a 3-week event window around the announcement date in Panel A and dollar value gains to target size in Panel B. All M\&A transactions in the sample involve a public acquirer from a developed market and a public target from an emerging market. Weekly abnormal returns are calculated using a market model and are continuously compounded, then standardized to monthly units. Dollar value gains to target size are calcuated as acquirer returns mutltiplied by acquirer market capitalization and normalized by the size of the target firm. This value is log-transformed and winsorized. Crisis period is a dummy variable that takes on a value of one if the target country is in a currency crisis. EMBI is the relative value of the JP Morgan Emerging Market's Bond Index (EMBI) spread. Mean coefficient estimates are reported with robust standard errors in parentheses. *, $* *$, and ${ }^{* * *}$ denote statistical significance at the $10 \%, 5 \%$, and $1 \%$ levels.

\begin{tabular}{lcc|cc}
\hline & $\mathbf{1 a}$ & $\mathbf{2 a}$ & $\mathbf{1 b}$ & $\mathbf{2 b}$ \\
\hline \hline EMBI Spread & $0.103^{* *}$ & & 0.028 & \\
& $(0.045)$ & & $(0.019)$ & \\
Crisis & & -0.014 & & -0.009 \\
& & $(0.017)$ & & $(0.010)$ \\
Target Country & & & & \\
Fixed Effects & Yes & Yes & Yes & Yes \\
$R$-squared & 0.051 & 0.021 & 0.092 & 0.051 \\
$N$ & 293 & 353 & 210 & 252 \\
\hline
\end{tabular}


Table 9 (Panel A): Robustness Checks

\begin{tabular}{|c|c|c|c|c|c|c|c|c|c|}
\hline \multirow{2}{*}{$\begin{array}{c}\text { All Targets } \\
\text { Panel A } \\
\end{array}$} & \multicolumn{5}{|c|}{ 3-Week Window } & \multicolumn{4}{|c|}{ 3-Day Window } \\
\hline & 1 & 2 & 3 & 4 & 5 & 6 & 7 & 8 & 9 \\
\hline Intercept & $\begin{array}{l}-0.000 \\
(0.004)\end{array}$ & $\begin{array}{c}-0.042 * * * \\
(0.015)\end{array}$ & $\begin{array}{l}-0.034 * \\
(0.018)\end{array}$ & $\begin{array}{l}-0.029 \\
(0.018)\end{array}$ & $\begin{array}{r}-0.034 \\
(0.023)\end{array}$ & $\begin{array}{l}-0.008 \\
(0.004)\end{array}$ & $\begin{array}{l}0.046 \\
(0.006)\end{array}$ & $\begin{array}{l}-0.000 \\
(0.006)\end{array}$ & $\begin{array}{l}0.040 * * \\
(0.017)\end{array}$ \\
\hline Emerging-Market Target & & $\begin{array}{l}0.023 * \\
(0.014)\end{array}$ & $\begin{array}{l}0.032 * \\
(0.017)\end{array}$ & $\begin{array}{l}-0.004 \\
(0.020)\end{array}$ & $\begin{array}{l}-0.011 \\
(0.020)\end{array}$ & $\begin{array}{c}0.001 \\
(0.007)\end{array}$ & $\begin{array}{l}-0.000 \\
(0.009)\end{array}$ & $\begin{array}{r}-0.001 \\
(0.007)\end{array}$ & $\begin{array}{l}-0.002 \\
(0.009)\end{array}$ \\
\hline Control & & & $\begin{array}{c}0.002 \\
(0.012)\end{array}$ & $\begin{array}{l}-0.012 \\
(0.014)\end{array}$ & $\begin{array}{l}-0.012 \\
(0.015)\end{array}$ & $\begin{array}{c}0.003 \\
(0.005)\end{array}$ & $\begin{array}{l}0.001 \\
(0.006)\end{array}$ & $\begin{array}{l}-0.001 \\
(0.005)\end{array}$ & $\begin{array}{l}-0.000 \\
(0.006)\end{array}$ \\
\hline $\begin{array}{l}\text { Emerging-Market Target* } \\
\text { Control }\end{array}$ & & & & $\begin{array}{c}0.066^{* *} \\
(0.027)\end{array}$ & $\begin{array}{c}0.056 * * \\
(0.027)\end{array}$ & $\begin{array}{r}0.029 * * \\
(0.013)\end{array}$ & $\begin{array}{l}0.037 * * * \\
(0.014)\end{array}$ & $\begin{array}{l}0.030 * * \\
(0.013)\end{array}$ & $\begin{array}{l}0.039 * * * \\
(0.015)\end{array}$ \\
\hline $\begin{array}{l}\text { Previous Relationship with } \\
\text { Target }\end{array}$ & & & & & $\begin{array}{c}0.011 \\
(0.015)\end{array}$ & & & & \\
\hline $\begin{array}{l}\text { TransactionValue / Acquirer } \\
\text { Mktcap }\end{array}$ & & & & & & $\begin{array}{c}0.013 \\
(0.007)\end{array}$ & $\begin{array}{l}0.017 \\
(0.013)\end{array}$ & $\begin{array}{l}0.016^{* *} \\
(0.007)\end{array}$ & $\begin{array}{l}0.017 \\
(0.013)\end{array}$ \\
\hline Diversifing Acquisition & & & & & & & & $\begin{array}{l}-0.002 \\
(0.005)\end{array}$ & $\begin{array}{r}-0.003 \\
(0.006)\end{array}$ \\
\hline Tender Offer & & & & & & & & $\begin{array}{l}-0.004 \\
(0.006)\end{array}$ & $\begin{array}{l}-0.004 \\
(0.008)\end{array}$ \\
\hline $\begin{array}{l}\text { Percent Stock / All } \\
\text { consideration known }\end{array}$ & & & & & & & & $\begin{array}{l}0.000 \\
(0.001)\end{array}$ & $\begin{array}{l}0.000 \\
(0.001)\end{array}$ \\
\hline Acquirer Market to Book & & & & & & & & $\begin{array}{l}0.001 \\
(0.000)\end{array}$ & $\begin{array}{l}-0.001 \\
(0.001)\end{array}$ \\
\hline Acquirer Leverage & & & & & & & & $\begin{array}{l}0.017 \\
(0.024)\end{array}$ & $\begin{array}{l}0.054 \\
(0.068)\end{array}$ \\
\hline Acquirer Marketcap & & & & & & & & $\begin{array}{l}0.000 \\
(0.000)\end{array}$ & $\begin{array}{l}0.000 * * * \\
(0.000)\end{array}$ \\
\hline Acquirer Firm Fixed Effects & No & Yes & Yes & Yes & Yes & No & Yes & No & Yes \\
\hline Country Fixed Effects & No & No & No & No & No & No & No & No & Yes \\
\hline$R$-squared & 0.000 & 0.206 & 0.348 & 0.352 & 0.366 & 0.0375 & 0.247 & 0.072 & 0.251 \\
\hline$N$ & 1426 & 1426 & 973 & 973 & 935 & 507 & 507 & 490 & 490 \\
\hline
\end{tabular}


Notes: This table summarizes the results of regressions where the dependent variable is abnormal returns for acquirer firms during a 3-week and 3-day event window around the announcement date on characteristics of the involved firms. The M\&A transactions in the sample involve publicly listed developed-market acquirers and pooled publicly listed targets from the emerging and developed markets in the sample. Weekly abnormal returns are calculated using a market model and are continuously compounded, then standardized to monthly units in columns 1-5. The acquisition of control is a dummy variable identified if the acquirer holds $50 \%$ or more of the target firm's equity following the acquisition and did not previously have control. Previous relationship is a dummy variable that takes on a value of one if the acquirer held equity in the target firm prior to the acquisition. Diversification is a dummy variable that takes on a value of one if the absolute value of the difference in SIC codes between acquirer and target is 1000 or greater. Other controls include deal characterisitics such as tender offers, transaction value as a fraction of the acquirer's market capitalization, percent stock offered, acquirer-firm characterisitics such as size, marketto-book and leverage. Mean coefficient estimates are reported with robust standard errors in parentheses. ${ }^{*}, * *$, and ${ }^{* * *}$ denote statistical significance at the $10 \%, 5 \%$, and $1 \%$ levels. 
Table 9 (Panel B): Additional Tests

Notes: This table summarizes the results of regressions where the dependent variable is abnormal returns for acquirer firms during a 3-week event window around the announcement date. Diversification is a dummy variable that takes on a value of one if the absolute value of the difference in SIC codes between acquirer and target is 1000 or greater. Other controls include a previous relationship between the acquirer and target and previous acquisitions by the acquirer in emerging markets and the target's country. *, **, and *** denote statistical significance at the $10 \%, 5 \%$, and $1 \%$ levels, respectively.

Emerging-Market Targets, 3-Week Window

\begin{tabular}{|c|c|c|c|c|c|c|c|c|}
\hline Panel B & 1 & 2 & 3 & 4 & 5 & 6 & 7 & 8 \\
\hline Intercept & $\begin{array}{l}-0.022 \\
(0.019)\end{array}$ & $\begin{array}{l}-0.027 \\
(0.018)\end{array}$ & $\begin{array}{l}0.018^{*} \\
(0.010)\end{array}$ & $\begin{array}{l}0.018^{* *} \\
(0.008)\end{array}$ & $\begin{array}{c}0.007 \\
(0.010)\end{array}$ & $\begin{array}{c}0.007 \\
(0.009)\end{array}$ & $\begin{array}{l}-0.004 \\
(0.010)\end{array}$ & $\begin{array}{l}-0.002 \\
(0.010)\end{array}$ \\
\hline Majority Control & & $\begin{array}{c}0.044^{* * *} \\
(0.014)\end{array}$ & & & $\begin{array}{c}0.042^{* * *} \\
(0.015)\end{array}$ & $\begin{array}{c}0.042 * * * \\
(0.015)\end{array}$ & $\begin{array}{c}0.047 * * * \\
(0.016)\end{array}$ & $\begin{array}{l}0.038^{* *} \\
(0.018)\end{array}$ \\
\hline $\begin{array}{l}\text { \# Previous } \\
\text { Acquisitions in } \\
\text { Country }\end{array}$ & $\begin{array}{c}0.013^{* *} \\
(0.006)\end{array}$ & $\begin{array}{c}0.010 \\
(0.006)\end{array}$ & & & & & & \\
\hline $\begin{array}{l}\text { Previous } \\
\text { Acquistions with } \\
\text { Positive Returns (1 } \\
\text { Year, By Country) }\end{array}$ & & & $\begin{array}{l}-0.007 \\
(0.014)\end{array}$ & & & & & \\
\hline $\begin{array}{l}\text { Previous } \\
\text { Acquistions with } \\
\text { Positive Returns ( } 2 \\
\text { Years, By Country) }\end{array}$ & & & & $\begin{array}{l}-0.015 \\
(0.017)\end{array}$ & & & & \\
\hline $\begin{array}{l}\text { Diversifing } \\
\text { Acquisition } \\
\text { Previous Emerging- } \\
\text { Market Targets }\end{array}$ & & & & & $\begin{array}{l}-0.003 \\
(0.013)\end{array}$ & & $\begin{array}{c}0.005 \\
(0.015)\end{array}$ & \\
\hline $\begin{array}{l}\text { Previous Country } \\
\text { Targets }\end{array}$ & & & & & & $\begin{array}{l}-0.005 \\
(0.014)\end{array}$ & & \\
\hline $\begin{array}{l}\text { Previous } \\
\text { Relationship } \\
\text { Previous }\end{array}$ & & & & & & & & $\begin{array}{l}-0.002 \\
(0.016)\end{array}$ \\
\hline Relationship* & & & & & & & & 0.015 \\
\hline $\begin{array}{l}\text { Control } \\
\text { Country Fixed } \\
\text { Effects }\end{array}$ & Yes & Yes & Yes & Yes & No & No & No & $\begin{array}{c}(0.029) \\
\text { No }\end{array}$ \\
\hline $\begin{array}{l}R \text {-squared } \\
N\end{array}$ & $\begin{array}{c}0.009 \\
415\end{array}$ & $\begin{array}{c}0.052 \\
254\end{array}$ & $\begin{array}{c}0.0006 \\
392\end{array}$ & $\begin{array}{c}0.002 \\
373\end{array}$ & $\begin{array}{c}0.041 \\
216\end{array}$ & $\begin{array}{c}0.041 \\
216\end{array}$ & $\begin{array}{c}0.042 \\
254\end{array}$ & $\begin{array}{l}0.04 \\
241\end{array}$ \\
\hline
\end{tabular}

